NASA/TM-2010-216823

\title{
Design of Fiber Reinforced Foam Sandwich Panels for Large Ares V Structural Applications
}

Brett A. Bednarcyk, Steven M. Arnold, and Dale A. Hopkins

Glenn Research Center, Cleveland, Ohio 


\section{NASA STI Program . . . in Profile}

Since its founding, NASA has been dedicated to the advancement of aeronautics and space science. The NASA Scientific and Technical Information (STI) program plays a key part in helping NASA maintain this important role.

The NASA STI Program operates under the auspices of the Agency Chief Information Officer. It collects, organizes, provides for archiving, and disseminates NASA's STI. The NASA STI program provides access to the NASA Aeronautics and Space Database and its public interface, the NASA Technical Reports Server, thus providing one of the largest collections of aeronautical and space science STI in the world. Results are published in both non-NASA channels and by NASA in the NASA STI Report Series, which includes the following report types:

- TECHNICAL PUBLICATION. Reports of completed research or a major significant phase of research that present the results of NASA programs and include extensive data or theoretical analysis. Includes compilations of significant scientific and technical data and information deemed to be of continuing reference value. NASA counterpart of peer-reviewed formal professional papers but has less stringent limitations on manuscript length and extent of graphic presentations.

- TECHNICAL MEMORANDUM. Scientific and technical findings that are preliminary or of specialized interest, e.g., quick release reports, working papers, and bibliographies that contain minimal annotation. Does not contain extensive analysis.

- CONTRACTOR REPORT. Scientific and technical findings by NASA-sponsored contractors and grantees.
- CONFERENCE PUBLICATION. Collected papers from scientific and technical conferences, symposia, seminars, or other meetings sponsored or cosponsored by NASA.

- SPECIAL PUBLICATION. Scientific, technical, or historical information from NASA programs, projects, and missions, often concerned with subjects having substantial public interest.

- TECHNICAL TRANSLATION. Englishlanguage translations of foreign scientific and technical material pertinent to NASA's mission.

Specialized services also include creating custom thesauri, building customized databases, organizing and publishing research results.

For more information about the NASA STI program, see the following:

- Access the NASA STI program home page at http://www.sti.nasa.gov

- E-mail your question via the Internet to help@ sti.nasa.gov

- Fax your question to the NASA STI Help Desk at $443-757-5803$

- Telephone the NASA STI Help Desk at 443-757-5802

- Write to: NASA Center for AeroSpace Information (CASI) 7115 Standard Drive Hanover, MD 21076-1320 
NASA/TM-2010-216823

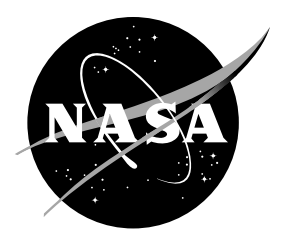

\section{Design of Fiber Reinforced Foam Sandwich Panels for Large Ares V Structural Applications}

Brett A. Bednarcyk, Steven M. Arnold, and Dale A. Hopkins

Glenn Research Center, Cleveland, Ohio

Prepared for the

51st Structures, Structural Dynamics, and Materials Conference

cosponsored by AIAA, ASME, ASCE, AHS, and ASC

Orlando, Florida, April 12-15, 2010

National Aeronautics and

Space Administration

Glenn Research Center

Cleveland, Ohio 44135 
Trade names and trademarks are used in this report for identification only. Their usage does not constitute an official endorsement, either expressed or implied, by the National Aeronautics and Space Administration.

Level of Review: This material has been technically reviewed by technical management.

Available from

NASA Center for Aerospace Information 7115 Standard Drive

Hanover, MD 21076-1320
National Technical Information Service 5301 Shawnee Road Alexandria, VA 22312

Available electronically at http://gltrs.grc.nasa.gov 


\title{
Design of Fiber Reinforced Foam Sandwich Panels for Large Ares V Structural Applications
}

\author{
Brett A. Bednarcyk, Steven M. Arnold, and Dale A. Hopkins \\ National Aeronautics and Space Administration \\ Glenn Research Center \\ Cleveland, Ohio 44135
}

\begin{abstract}
The preliminary design of three major structural components within NASA's Ares V heavy lift vehicle using a novel fiber reinforced foam composite sandwich panel concept is presented. The Ares V payload shroud, interstage, and core intertank are designed for minimum mass using this panel concept, which consists of integral composite webs separated by structural foam between two composite facesheets. The HyperSizer structural sizing software, in conjunction with NASTRAN finite element analyses, is used. However, since HyperSizer does not currently include a panel concept for fiber reinforced foam, the sizing was performed using two separate approaches. In the first, the panel core is treated as an effective (homogenized) material, whose properties are provided by the vendor. In the second approach, the panel is treated as a blade stiffened sandwich panel, with the mass of the foam added after completion of the panel sizing. Details of the sizing for each of the three Ares $\mathrm{V}$ components are given, and it is demonstrated that the two panel sizing approaches are in reasonable agreement for thinner panel designs, but as the panel thickness increases, the blade stiffened sandwich panel approach yields heavier panel designs. This is due to the effects of local buckling, which are not considered in the effective core property approach.
\end{abstract}

\section{Introduction}

NASA's Ares V heavy lift vehicle is currently being designed to deliver cargo to low Earth orbit and the Moon as part of the United States' next-generation space fleet. As shown in Figure 1, Ares V consists of two vertically stacked stages (core stage and Earth departure stage), along with two 5.5 stage solid rocket boosters (SRBs). As is typical with launch vehicles, structural mass is a dominant design driver for Ares V. Thus, NASA is currently exploring the use of fiber reinforced polymer composites for structural applications within Ares V. To support this effort, in 2008 NASA began the Advanced Composite Technologies (ACT) project under the Exploration Technologies Development Program, with the goal of advancing composite materials and structures technologies for insertion into Ares V. Three major structural components, as indicated in Figure 2, were targeted by the ACT project for infusion of composite technologies to reduce structural mass: the payload shroud, the interstage, and the core intertank. The $10 \mathrm{~m}$ diameter, $23.7 \mathrm{~m}$ long payload shroud sits atop the Ares $\mathrm{V}$ vehicle to protect the payload (the Altair lunar lander in Figs. 1 and 2) during ascent. The $10 \mathrm{~m}$ diameter, $15.5 \mathrm{~m}$ long interstage connects the Earth departure stage to the core stage. Finally, the $10 \mathrm{~m}$ diameter, $8.4 \mathrm{~m}$ long core intertank is located between the liquid oxygen and liquid hydrogen tanks within the core stage. The core intertank also contains the forward connection points for the SRBs and is thus very highly loaded. The baseline configuration, derived from the Space Shuttle External Tank design, also includes a thrust beam, which traverses the intertank and connects the two SRBs.

A number of composite panel concepts were selected by the ACT project to be compared for each of the three Ares V components based on preliminary designs. The panel concepts being considered are uniaxial stiffened, hat stiffened, iso/orthogrid, corrugated sandwich, aluminum honeycomb sandwich, foam core sandwich, PRSEUS, and fiber reinforced foam (FRF) core sandwich. This paper presents the preliminary design of the Ares $\mathrm{V}$ shroud, interstage, and intertank using the FRF core sandwich panel concept.

\section{Fiber Reinforced Foam (FRF) Sandwich Panels}

Fiber reinforced foam sandwich panels are formed by winding fibers around sections of stiff foam, stacking the wound foam section, adding dry facesheet preforms, and infusing resin into the panel. The dry panel preform can also be stitched prior to resin infusion to improve the damage tolerance of the finished panel. The resulting panels, as shown in Figure 3, include facesheets and integral webs. The foam can be removed after the resin has been infused and cured, and panels with bidirectional integral webs can be manufactured as well. The FRF core panels considered herein are manufactured by WebCore Technologies (Refs. 1 and 2), who provided the core material properties employed in the design, via a patented process. 


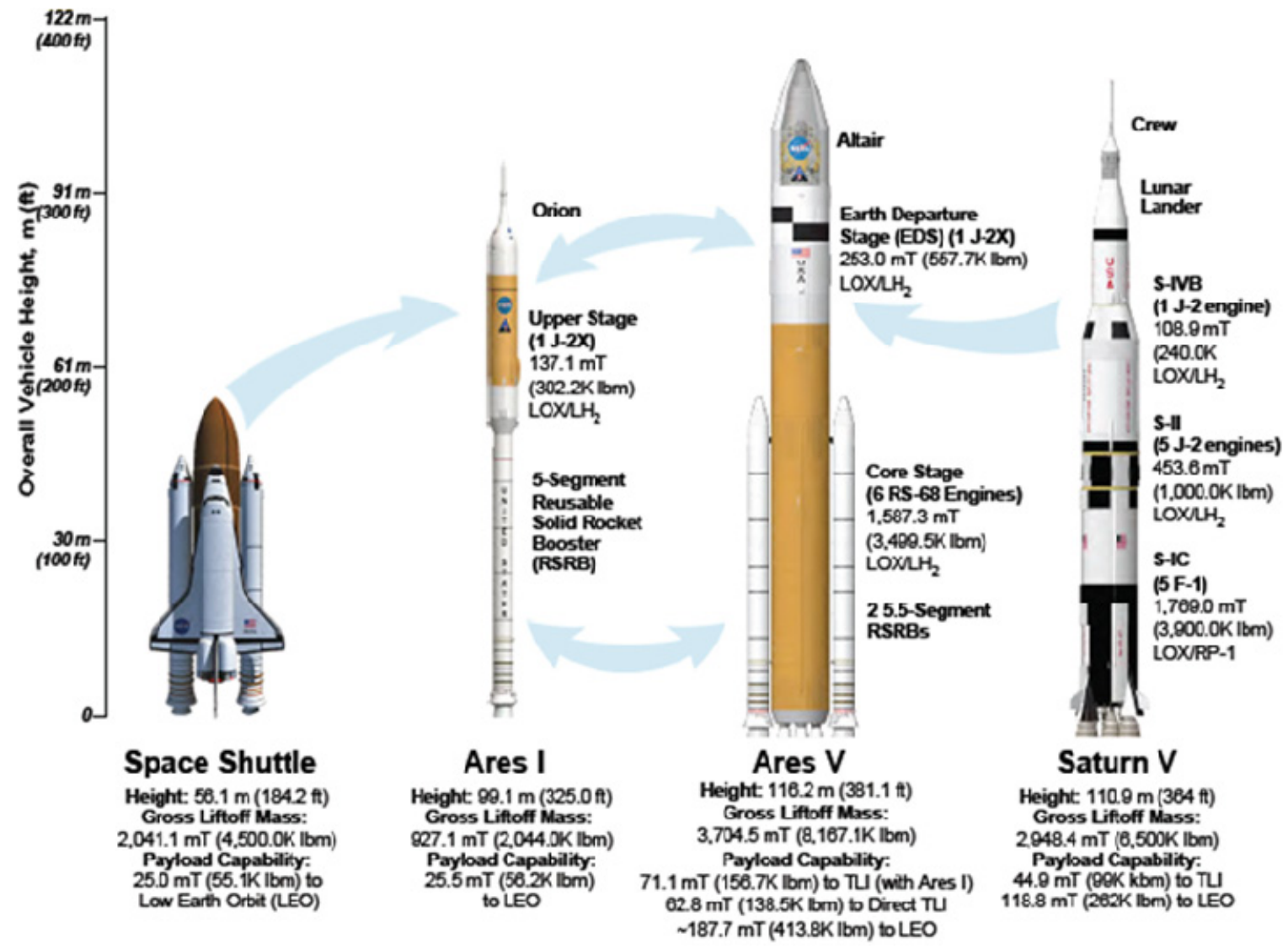

Figure 1.-Comparison of NASA's Ares V heavy lift vehicle with other NASA launch vehicles.

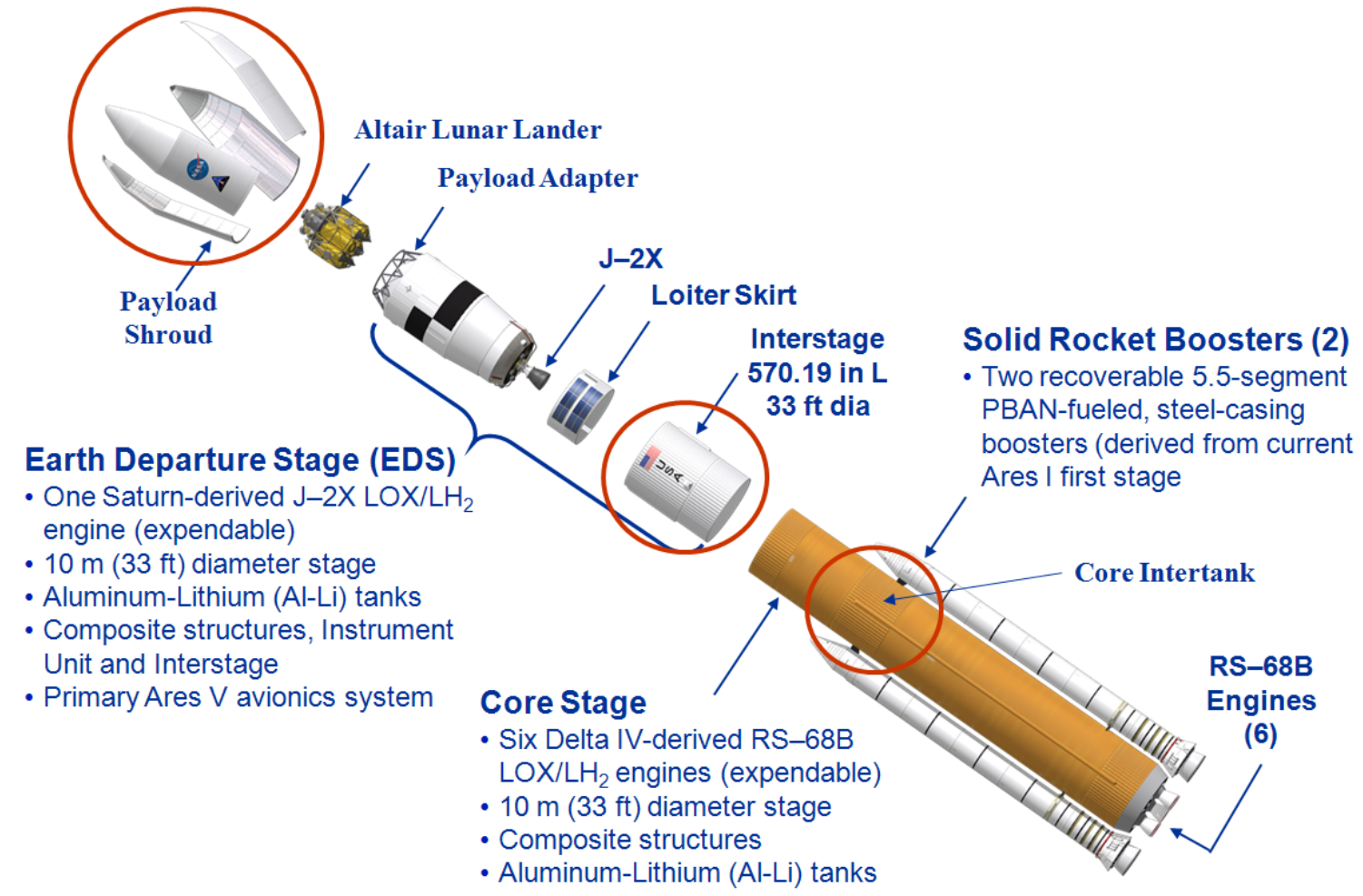

Figure 2.-Ares $\mathrm{V}$ major components. 


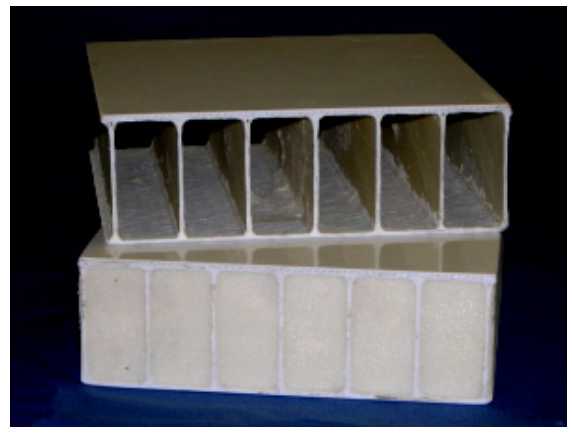

(a)

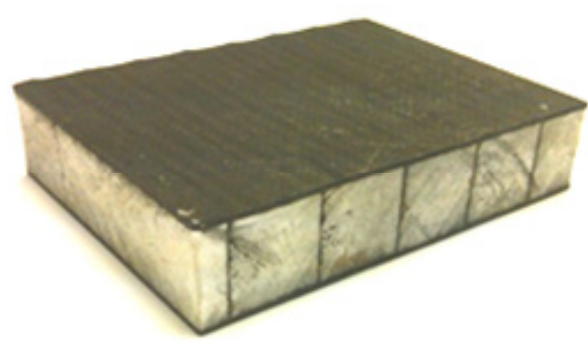

(b)

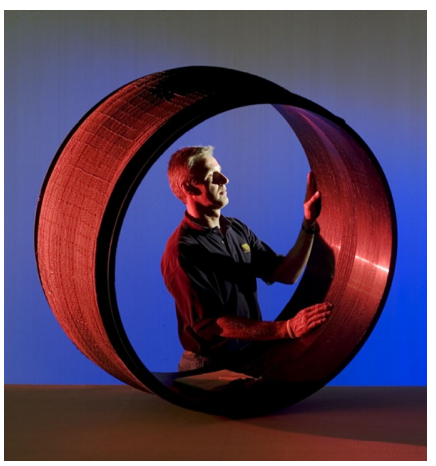

(c)

Figure 3.-(a) WebCore FRF panels with and without foam removed. (b) Typical FRF panel. (c) FRF engine casing with double curvature manufactured by WebCore Technologies.

\section{Preliminary Design Procedure}

The payload shroud, interstage, and core intertank were designed using NASTRAN (Ref. 3) shell and beam loads finite element models (FEMs) in conjunction with the HyperSizer structural sizing software (Ref. 4). In this procedure, the shape of the structure and the load cases are defined in the FEM, the solution of which provides shell and beam element loads. These loads are then read by HyperSizer, wherein the shell and beam elements are allocated to a user specified number of structural components. A component comprised of shell elements typically represents a particular panel within HyperSizer. The element loads for every load case from the FEM solution are statistically processed to arrive at design-to loads for each panel and beam component for both strength and buckling. For each panel and beam component, the user specifies candidate designs by selecting the panel type (i.e., hat stiffened or honeycomb sandwich), the upper and lower limits of the local geometric parameters (i.e., panel height, facesheet thickness, web spacing), the number of permutations to consider for each geometric parameter, and the candidate materials for each panel subcomponent (i.e., facesheet materials, foam or honeycomb core materials, web materials). HyperSizer then uses internal analytical localization techniques to determine the design-to stress and strain fields throughout the panel or beam based on the panel level design-to loads. Using these local design-to fields (as well as the panel design-to loads), the code then evaluates the panel or beam candidate designs based on the candidate material properties (stress/strain allowables and stiffnesses). HyperSizer considers a wide array of failure modes for strength and stability such as local buckling of webs and facesheets, panel buckling, composite strength failure (i.e., max strain, Tsai-Wu, LaRC03), crippling, facesheet wrinkling, honeycomb intracell dimpling, shear crimping, core crushing, and core shear failure. For every potential failure mode for each candidate panel or beam and for all specified load cases, HyperSizer determines a margin of safety. The lightest candidate beam or panel for which all margins of safety are positive is then the optimal design (in terms of mass), and this candidate is selected. The lightest candidate is found by first ranking all candidates based on mass, and then finding the first (lightest) candidate that provides all positive margins. This procedure is performed for all panel and beam components throughout the structure to arrive at a new optimized global design given the loads provided by the FEM solution. However, now that a new design has been found that is different than that used in the FEM to determine the loads, the FEM must be updated to reflect the new design and new loads determined. The new loads must then be provided to HyperSizer to determine a new optimized design, and the procedure repeats iteratively until convergence has been achieved. A software product called HyperFEA (Ref. 5), which automates this procedure of iterating between NASTRAN and HyperSizer, was used in the present investigation.

HyperSizer does not currently include a family of stiffened panels capable of fully sizing the FRF core panel concept. That is, the software presently does not allow the sizing and material selection of a FRF panel facesheet, web, web spacing, panel thickness, and foam. Two methods were thus used as a workaround. The first is to simply model the FRF core as an equivalent material, with effective (smeared) material properties, using the standard HyperSizer sandwich panel family. This method is analogous to the standard HyperSizer method for sizing honeycomb sandwich panels. The facesheet materials are arbitrary, while the core material must be a "honeycomb" material within HyperSizer. These "honeycomb" materials have effective through-thickness normal and shear stiffness and strength, but no in-plane stiffness or strength. As such, honeycomb materials do not contribute to the in-plane stiffness of the panel, rather, all panel in-plane loads are carried by the facesheets. Effective "honeycomb" material properties for standard FRF cores were provided by WebCore (Refs. 6 and 7) for use in sizing the FRF 
TABLE 1.-FRF CORE MATERIAL PROPERTIES (REFS. 1 AND 7)

\begin{tabular}{|l|c|c|c|c|c|c|c|c|c|}
\hline & $\begin{array}{c}\text { Density } \\
\text { (pcf) }\end{array}$ & $\begin{array}{c}\text { Et } \\
\mathbf{( k s i )}\end{array}$ & $\begin{array}{c}\text { Ec } \\
\mathbf{( k s i )}\end{array}$ & $\begin{array}{c}\text { Gw } \\
\text { (ksi) }\end{array}$ & $\begin{array}{c}\text { GI } \\
\text { (ksi) }\end{array}$ & $\begin{array}{c}\text { Ftu } \\
\text { (psi) }\end{array}$ & $\begin{array}{c}\text { Fsuw } \\
\text { (psi) }\end{array}$ & $\begin{array}{c}\text { Fsul } \\
\text { (psi) }\end{array}$ & $\begin{array}{c}\text { Fcus } \\
\text { (psi) }\end{array}$ \\
\hline WebCore A & 4.1 & 26.1 & 26.1 & 1.88 & 44.7 & 272 & 89 & 234 & 352 \\
\hline WebCore B & 7.3 & 128 & 128 & 10 & 161 & 595 & 89 & 1266 & 595 \\
\hline WebCore Light Bi & 7.5 & 68.0 & 68.0 & 9 & 35 & 1641 & 145 & 473 & 1641 \\
\hline TYCOR G6 Bi & 6.8 & 50 & 50 & 10 & 14 & 140 & 180 & 180 & 70 \\
\hline TYCOR 126-C06 & 11.7 & 314 & 314 & 147 & 212 & 710 & 764 & 538 & 2000 \\
\hline TYCOR 67-C18 & 6.9 & 70.4 & 70.4 & 27.4 & 40.8 & 355 & 240 & 389 & 362 \\
\hline TYCOR 92-C2 & 4.4 & 38.7 & 38.7 & 1.91 & 84.1 & 410 & 62 & 314 & 542 \\
\hline TYCOR 92-C6 & 5.4 & 156 & 156 & 2.24 & 77.1 & 687 & 120 & 667 & 1013 \\
\hline TYCOR 94-C1 & 3.9 & 23.1 & 23.1 & 1.90 & 37.5 & 305 & 60 & 231 & 355 \\
\hline
\end{tabular}

concept using the effective core material approach. The candidate effective core material properties are given in Table 1. The benefit of utilizing this approach is that standard core designs with reasonably well known properties are employed. The disadvantage of this approach is that the panel is not being fully optimized for the load state as the web spacing, web material, and foam material cannot be optimized. Rather, the details of the core geometry have already been captured within the core's effective properties.

The second approach employed for sizing the FRF core panels involves treating the panel as a blade stiffened sandwich panel in HyperSizer. This enables HyperSizer to optimize not only the panel height, facesheet thickness, and facesheet materials (as in the effective core material property approach), but also the web spacing, web thickness, and web material. The foam and its effect on the panel performance, however, are not captured in this approach. To account for the stabilizing effect of the foam on the local buckling of the webs and the facesheets, the crippling failure modes typically considered for a blade stiffened sandwich panel were disabled. Furthermore, a positive factor of 3 was placed on the local buckling failure modes. This essentially allows the webs and facesheets to attain positive margins for loads up to three times their buckling loads calculated within HyperSizer. This factor of 3 is arbitrary, but was chosen through trial and error so that a reasonable web spacing would be chosen by HyperSizer in several cases. It is noted that one particular design of a FRF panel based on this approach was confirmed to provide positive local buckling margins in a detailed Abaqus shell Eigenvalue model (Ref. 7). The final step of the blade stiffened sandwich approach involves adding the mass of the foam to the sized blade stiffened sandwich panel mass after completing the sizing.

\section{Results and Discussion}

\section{A. Payload Shroud}

The NASTRAN FEM employed for the payload shroud is shown in Figure 4. The model consists of three major panel components, the upper nose, lower nose, and barrel, which are all sized with the FRF panel concept. The remaining panels represent doors and penetrations and are not sized. These panels are assigned a thin, weak design such that they carry minimal load, but still enable the shroud to be closed. Beam components in the model consist of three ring frames at the bottom of each major panel, frames around the cutouts and doors, and four separation rails that divide the shroud into four petals. The ring frames are sized as composite I-beams, while the penetration frames are sized as composite J-beams. The separation rails are not sized, but rather are assigned a fixed aluminum alloy J-beam design with a unit mass of $2.34 \mathrm{~kg} / \mathrm{m}$. This design is intended to be relatively weak such that the rails do not carry a large amount of load. The actual design of the separation rails requires consideration of the details of the joints between the petals along with the separation procedure required as the shroud is jettisoned (see Fig. 2). It should be noted that the choice of the number of panel components to be used in the sizing can have a significant effect on the design. Three large acreage panel components are shown in Figure 4. A more detailed design would likely use a greater number of such components, including separate components to represent build ups around the cut outs. This enables HyperSizer to better optimize the structure to the local loads. In the case of the shroud, because the loads are relatively small, this is less of an issue than it is in other Ares V structures. 


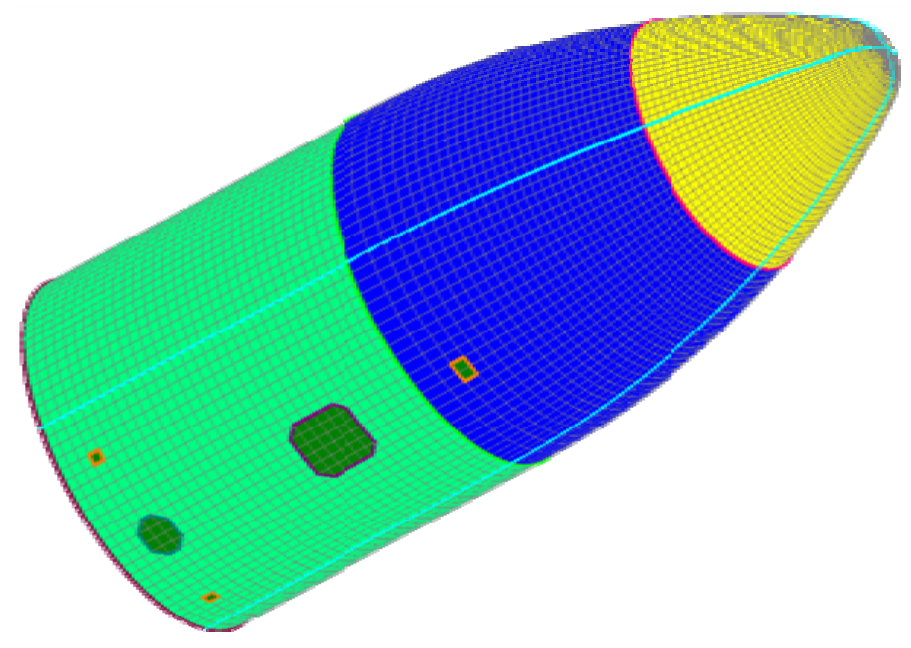

Figure 4.-Ares $V$ payload shroud FEM.

Six load cases are considered in the payload shroud design, illustrated in Figure 5. The Max G load case involves pure axial acceleration, and is paired with a constant thermal load. The remaining five load cases are associated with the maximum dynamic pressure load (Max Q) during ascent. The pure Max Q load case involves a maximum dynamic pressure, along with an additional pressure to account for off-nominal conditions. These dynamic pressures are distributed to the external surface of the shroud based on CFD simulations of the ascent. In addition, a negative internal pressure is superimposed on the entire shroud to account for the worst case venting situation during ascent in which supersonic flow can cause a negative pressure to be pulled. Finally, an axial acceleration load is present in the Max Q load case. The cumulative axisymmetric pressure profile for the Max Q load case applied to the shroud is shown in Figure 6(a). The remaining four load cases all involve the Max Q $\alpha$ condition (Max Q applied at an angle of attack), wherein the Max Q condition is applied with the vehicle at an angle of $7^{\circ}$ from vertical. This causes an asymmetry of the pressure profile, as shown in Figure 6(b). To account for interaction between the cutouts and the asymmetric pressure profile, the pressure profile is clocked at $0^{\circ}, 90^{\circ}, 180^{\circ}$, and $270^{\circ}$ with respect to the cutout locations. The FEM is also fully constrained at the aft end. Note that the magnitudes of the loads are not currently releasable.

For both the effective core property approach and the blade stiffened panel approach, effective laminate material properties, derived from an IM7/977-3 quasi-isotropic [0/ $\pm 45 / 90]_{\mathrm{s}}$ laminate, were used for the facesheets and webs. In HyperSizer, such effective laminate materials are determined from classical lamination theory for a given laminate based on known ply properties, and the laminate is treated as an orthotropic material. This enables the facesheets and webs to be sized by thickness rather than using an explicit ply-by-ply design, which is beneficial for performing efficient preliminary trade studies. The disadvantage is that the sized facesheets and webs are most likely approximate as a layup that corresponds exactly to the effective laminate thickness and ply percentages is unlikely. Further, the effective laminate material allowables are derived from the ply-based allowables using classical lamination theory, and this must also be viewed as an approximation. The effective laminate material properties employed for the payload shroud sizing are given in Table 2. The minimum gage assumptions employed for the facesheet and web thicknesses were 0.022 in. (equivalent to 4 plies), while the minimum gage assumed for the beam sections was $0.044 \mathrm{in}$. (equivalent to 8 plies). The thicknesses of the two facesheets were permitted to size independently, however, in all cases, the facesheets sized to the same thickness. An ultimate load factor of 1.4 and a limit load factor of 1.0 were employed, as was a panel buckling knockdown factor of 0.65 . 


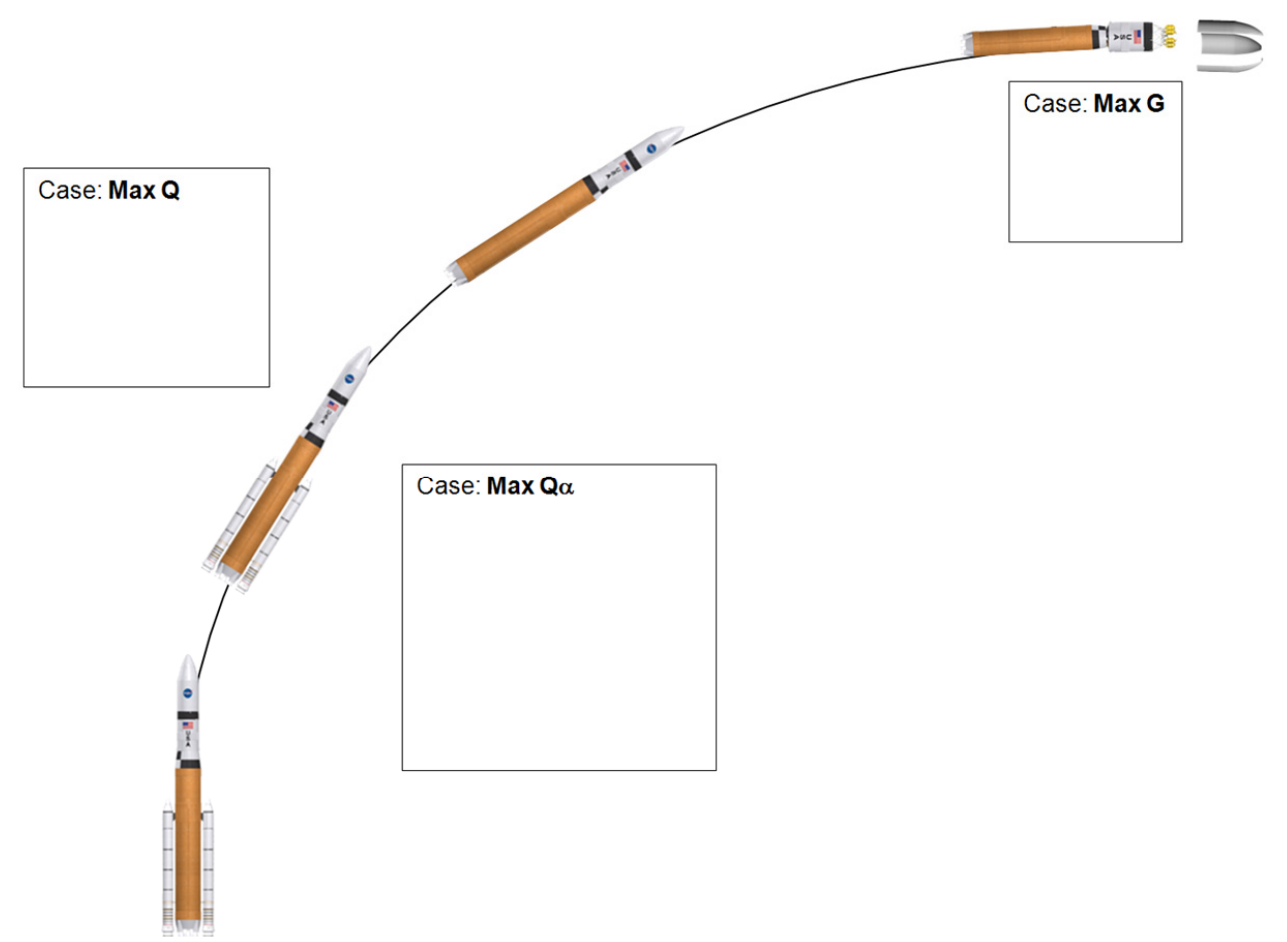

Figure 5.-Ares $\vee$ payload shroud load cases.

(a)

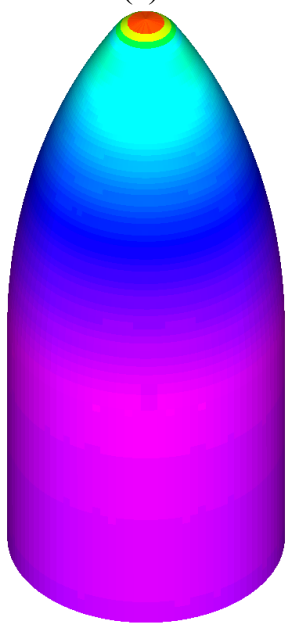

(b)

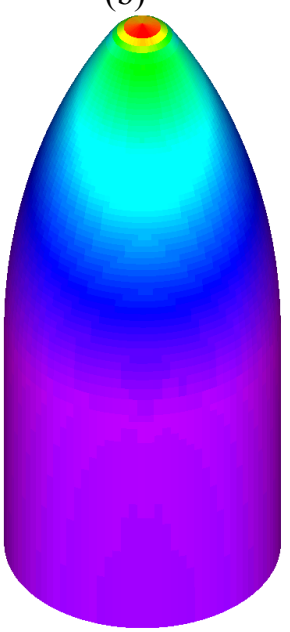

Figure 6.-Ares V Payload Shroud applied pressure profile for (a) Max Q load case and (b) Max $Q \alpha 0^{\circ}$ load case.

TABLE 2.-PAYLOAD SHROUD EFFECTIVE LAMINATE PROPERTIES - [0/ $445 / 90] \mathrm{S}$ IM7/977-3

\begin{tabular}{|c|c|c|c|c|c|c|c|c|c|c|c|c|c|}
\hline $\begin{array}{c}\text { Temp } \\
\left({ }^{\circ} \mathrm{F}\right)\end{array}$ & $\begin{array}{l}\text { Density } \\
\text { (pcf) }\end{array}$ & $\begin{array}{c}\text { Et1 } \\
\text { (Msi) }\end{array}$ & $\begin{array}{c}\text { Et2 } \\
\text { (Msi) }\end{array}$ & $v \mathrm{t} 12$ & $\begin{array}{c}\text { Ec1 } \\
\text { (Msi) }\end{array}$ & $\begin{array}{c}\text { Ec2 } \\
\text { (Msi) }\end{array}$ & vc12 & $\begin{array}{c}\text { G12 } \\
\text { (Msi) }\end{array}$ & $\begin{array}{l}\text { Ftu1 } \\
\text { (ksi) }\end{array}$ & $\begin{array}{l}\text { Ftu2 } \\
\text { (ksi) }\end{array}$ & $\begin{array}{l}\text { Fcu1 } \\
\text { (ksi) }\end{array}$ & $\begin{array}{l}\text { Fcu2 } \\
\text { (ksi) }\end{array}$ & $\begin{array}{c}\text { Fsu12 } \\
\text { (ksi) }\end{array}$ \\
\hline-65 & 98.5 & 8.63 & 8.63 & 0.303 & 8.48 & 8.48 & 0.302 & 3.13 & 57.1 & 57.1 & 57.1 & 57.1 & 30.0 \\
\hline 75 & 98.5 & 8.41 & 8.41 & 0.313 & 8.26 & 8.26 & 0.313 & 3.20 & 75.1 & 75.1 & 74.3 & 74.3 & 40.5 \\
\hline 220 & 98.5 & 8.21 & 8.21 & 0.326 & 8.06 & 8.06 & 0.325 & 3.09 & 70.6 & 70.6 & 56.7 & 56.7 & 38.5 \\
\hline
\end{tabular}

Et1 $=0^{\circ}$ tensile Young's modulus; Et $2=90^{\circ}$ tensile Young's modulus; vt12 $=$ in-plane tensile Poisson ratio; Ec1 $=0^{\circ}$ compressive Young's modulus; Ec2 $=90^{\circ}$ compressive Young's modulus; vc12 $=$ in-plane compressive Poisson ratio; G12 = inplane shear modulus; Ftu $1=0^{\circ}$ ultimate tensile stress allowable; Ftu $2=90^{\circ}$ ultimate tensile stress allowable; Fcu $1=0^{\circ}$ ultimate compressive stress allowable; Fcu2 $=90^{\circ}$ ultimate compressive stress allowable; Fsu12 = ultimate in-plane shear stress allowable. 
The effective core property design and the blade stiffened design were iterated with HyperFEA approximately 15 times, wherein changes were made between some iterations to hone the variable bounds. In both cases, a well converged design was achieved with the margins of safety shown in Figure 7. As stated above, the negative margins for the separation rails and some cut out panels are expected as their components were not sized, but were rather provided weak designs such that they do not carry significant load. All other component margins are positive, with the ring frames attaining high positive margins. The fact that these ring frames sized to minimum gage, yet still have such high margins indicate that these ring frames are parasitic to the design from the standpoint of the structural capability of the shroud given the flight load cases considered.

The summaries for the payload shroud FRF panel designs are shown in Figure 8. For the effective core property approach, all three panel component designs used the least dense core (see Table 1) with a thickness of 1.625 in. The upper nose and lower nose facesheets sized to the 4 ply minimum gage thickness, while the barrel facesheets sized to a 5 ply thickness. The controlling failure mechanism for the lower nose and barrel was panel buckling, while, for the upper nose, it was facesheet wrinkling. For the blade stiffened sandwich panel approach, all three panel components were controlled by panel buckling and sized to $1 \mathrm{in}$. web spacing. The sized web thicknesses were 4, 5, and 4 ply equivalents for the upper nose, lower nose, and barrel, respectively, while all three component facesheet thicknesses sized to the 4 ply minimum gage. Finally, the sized core thicknesses were 1.5, 1, and 1.25 in., respectively, for the upper nose, lower nose, and barrel. It is noteworthy that the upper nose sized to the thickest core in the case of the blade stiffened panel approach, likely due to the high pressure concentration in the max Q $\alpha$ load case (see Fig. 6), whereas in the effective property approach, this was not the case. As shown in Figure 9, the max $\mathrm{Q} \alpha$ load case controls the entire payload shroud structure, aside from the separation rails.

(a)

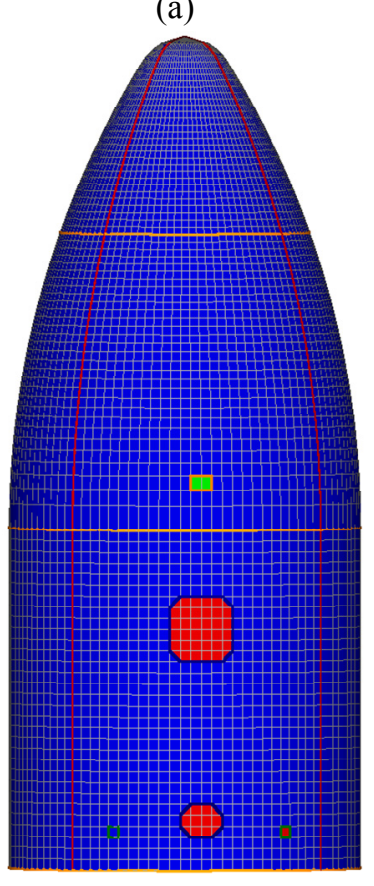

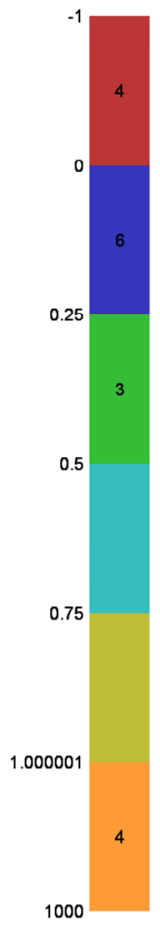

(b)

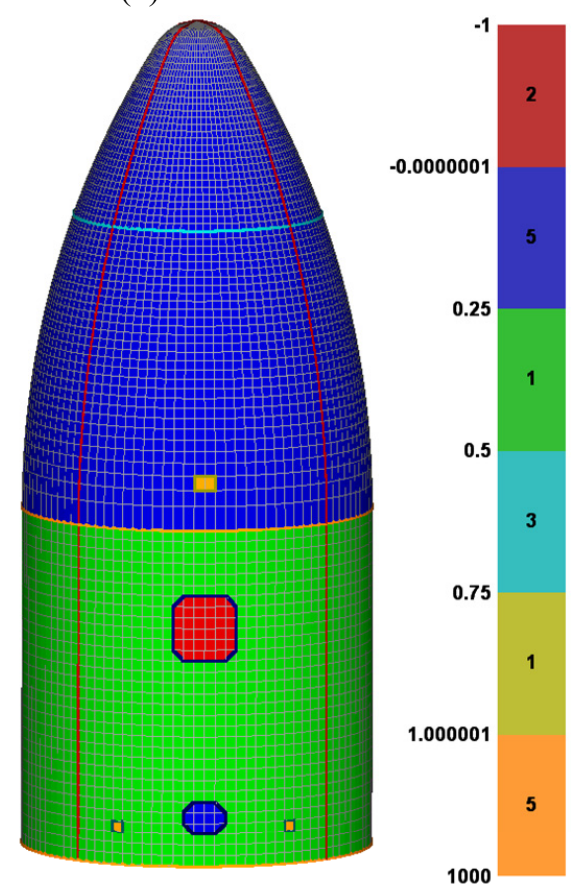

Figure 7.-Ares $V$ payload shroud FRF core sandwich panel design margins of safety for (a) the effective core property approach and (b) the blade stiffened sandwich panel approach. 
(a)

[Honeycomb "WebCore TYCOR 94-C1 4pcf", Density 2.256945E-03, Dry], 8 components $\square$

Upper Nose:

$.41 .3 \mathrm{~mm}$ (1 5/8") core

-4 ply facesheets

- Facesheet wrinkling

Lower Nose:

. $41.3 \mathrm{~mm}$ (1 5/8") core

- 4 ply facesheets

- Panel Buckling

Barrel:

- $41.3 \mathrm{~mm}$ (1 5/8") core

- 5 ply facesheets

- Panel Buckling

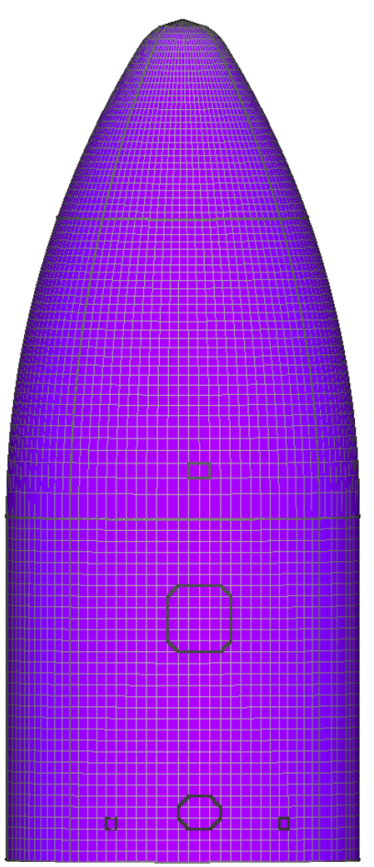

Upper Nose:

- $38.1 \mathrm{~mm}$ (1 1/2") core

- 4 ply facesheets

- 4 ply webs

- 25.4 mm (1") web spacing

-Panel Buckling

Lower Nose:

- $25.4 \mathrm{~mm}$ (1") core

- 4 ply facesheets

- 5 ply webs

- 25.4 mm (1") web spacing

- Panel Buckling

\section{Barrel:}

- $31.7 \mathrm{~mm}$ (1 1/4") core

- 4 ply facesheets

.4 ply webs

- 25.4 mm (1") web spacing

- Panel Buckling (b)

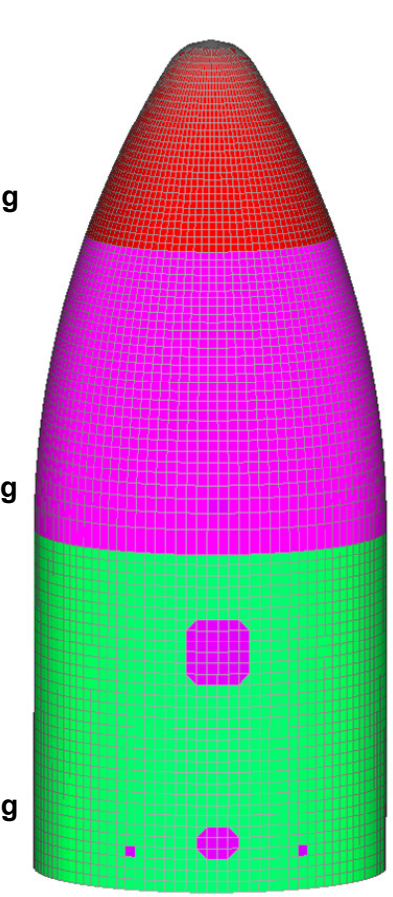

Figure 8.-Ares $V$ payload shroud FRF core sandwich panel design summary for (a) the effective core property approach and (b) the blade stiffened sandwich panel approach.

(a)

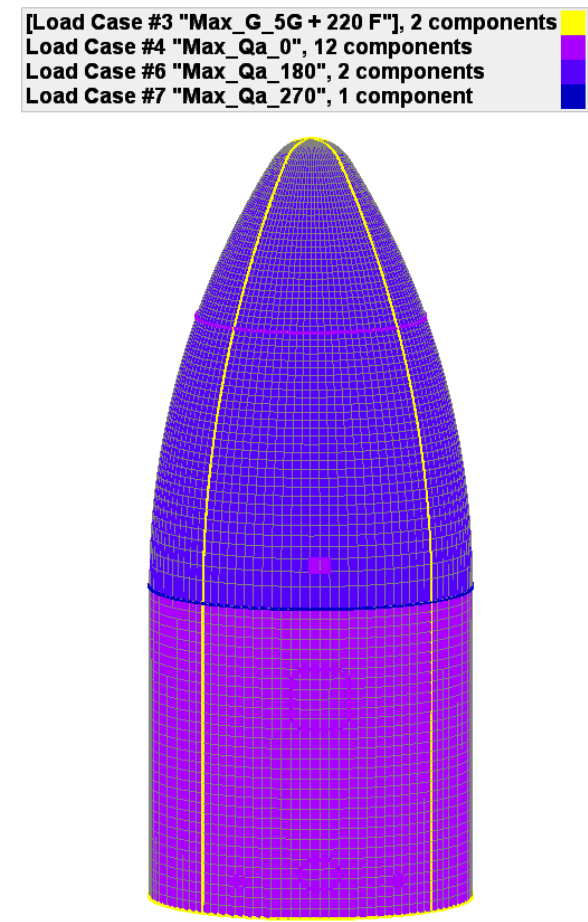

(b)

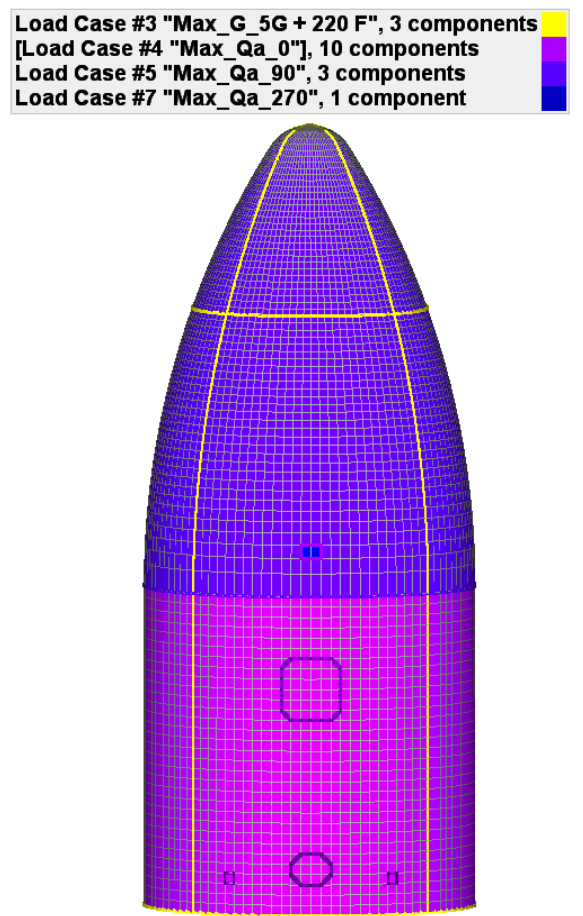

Figure 9.--Ares $V$ payload shroud FRF core sandwich panel design controlling load cases for (a) the effective core property approach and (b) the blade stiffened sandwich panel approach. 


\begin{tabular}{|c|c|c|}
\hline Configuration & $\begin{array}{l}\text { Added Foam Mass } \\
(\%)\end{array}$ & Smeared Unit Mass $\left(\mathrm{kg} / \mathrm{m}^{2}\right)$ \\
\hline FRF as Effective Properties & - & 4.49 \\
\hline Nose & - & 4.28 \\
\hline Barrel & - & 4.72 \\
\hline FRF as Blade Sandwich & 25.3 & 3.83 \\
\hline Nose & 24.3 & 3.81 \\
\hline Barrel & 26.4 & 3.86 \\
\hline
\end{tabular}

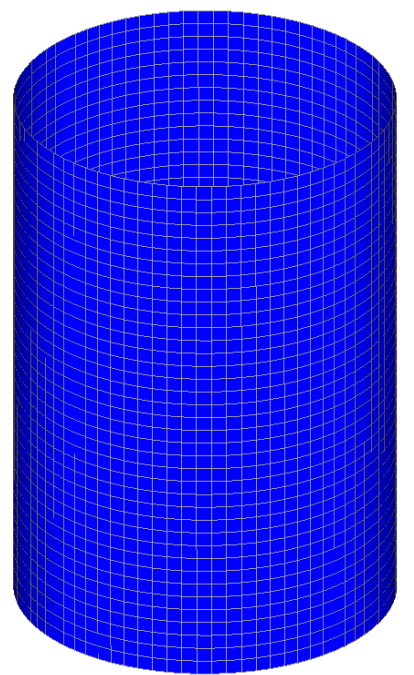

Figure 10.-Ares V interstage FEM.

The blade stiffened sandwich FRF design does not explicitly account for the foam present between the webs in the panels. Recall that a positive local buckling factor was employed to account for the stabilizing effect of the foam on the webs and facesheets. However, to assess the mass of the blade stiffened sandwich design, the mass of foam must be considered. Toward this end, a 2 pcf density foam was assumed and the appropriate mass added. Note that 2 pcf corresponds to a low-density Rohacell 31 IG closed-cell polymer foam (Ref. 8). The payload shroud panel mass summary is given in Table 3. Note that the separation rails and cut out panels are excluded from the smeared unit masses given, but all other structural components are included. As shown, the blade stiffened panel approach provided a total mass approximately $15 \%$ lighter than the effective property approach. This is mainly due to the decreased core thickness sized by the blade stiffened sandwich approach, which is likely allowable due to the fact that in this approach, the contribution of the webs to the panel stiffness is accounted for, whereas, in the effective core property approach, this contribution is neglected. This added stiffness allows the core to be thinner while still providing sufficient panel buckling resistance.

\section{B. Interstage}

The interstage is located near the middle of the Ares V stack (Fig. 2), and is thus more highly loaded than the shroud. The FEM employed for preliminary sizing of the interstage is simply a cylindrical shell, as shown in Figure 10, with no beam elements. The cylinder was treated as a single panel component for sizing within HyperSizer. A single load case, corresponding to the max Q condition, was considered. This involves an axial load, a shear load, and a bending moment, along with an external pressure. The magnitudes of these loads are not currently releasable. Care must be taken when applying loads such as these, that are essentially calculated based on modeling the vehicle stack as a beam, to a shell model so that the correct shear distribution is applied to the edge. Simply tying all of the nodes at one end of the cylinder to a central point where the loads are applied may (depending on the FE code) evenly distribute the shear load along the edge of the shell, which is not correct (Ref. 9). The end of the cylinder opposite the end where the loads are applied is constrained axially and in torsion, but free to translate radially. Ultimate and limit load factors of 1.4 and 1.0, respectively, were employed, along with a panel buckling knockdown factor of 0.65 . 
As in the sizing of the payload shroud, both the effective core property approach and the blade stiffened sandwich panel approach were used. Further, effective laminate material properties were used to represent the facesheets and webs in sizing the FRF interstage. However, a different material system, namely IM7/8552 with open hole compression allowables, was employed. As in the case of the shroud IM7/977-3 material, the effective laminate properties were determined from ply level properties using classical lamination theory within HyperSizer. Due to expected elevated temperatures during flight, the material properties at $120^{\circ} \mathrm{F}$ were used. An array of effective laminates with different percentages of $0 / \pm 45 / 90$ plies was considered. In all cases a $[10 \% 45,75 \% 0,15 \% 90]$ laminate was chosen for the facesheet, as this was the axially stiffest effective laminate considered. The properties of this effective laminate are given in Table 4 . In the case of the blade stiffened sandwich design approach, effective laminates with a maximum of $45 \% 0^{\circ}$ plies were considered. Three such effective laminates were chosen among the various panel designs described below, the properties of which are given in Table 5. A minimum gage thickness equivalent to 8 plies $(0.044 \mathrm{in}$.) was used for the facesheets, while a minimum gage thickness equivalent to 4 plies (0.022 in.) was used for the webs. The thicknesses of the two panel facesheets were required to be the same. In the effective core material sizing approach, the same core material properties, given in Table 1, were used.

TABLE 4.-ARES V FRF INTERSTAGE FACESHEET EFFECTIVE IM7/8552 OPEN HOLE COMPRESSION LAMINATE PROPERTIES AT $120^{\circ} \mathrm{F}$

\begin{tabular}{|c|c|c|c|c|c|c|c|c|c|c|c|c|c|}
\hline $\begin{array}{c}\text { Ply \% } \\
\mathbf{4 5}, \mathbf{0}, \mathbf{9 0}\end{array}$ & $\begin{array}{c}\text { Density } \\
\text { (pcf) }\end{array}$ & $\begin{array}{c}\text { Et1 } \\
\text { (Msi) }\end{array}$ & $\begin{array}{c}\text { Et2 } \\
\text { (Msi) }\end{array}$ & $\mathbf{v t 1 2}$ & $\begin{array}{c}\text { Ec1 } \\
\text { (Msi) }\end{array}$ & $\begin{array}{c}\text { Ec2 } \\
\text { (Msi) }\end{array}$ & vc12 & $\begin{array}{c}\text { G12 } \\
\text { (Msi) }\end{array}$ & $\begin{array}{c}\text { Ftu1 } \\
\text { (ksi) }\end{array}$ & $\begin{array}{c}\text { Ftu2 } \\
\text { (ksi) }\end{array}$ & $\begin{array}{c}\text { Fcu1 } \\
\text { (ksi) }\end{array}$ & $\begin{array}{c}\text { Fcu2 } \\
\text { (ksi) }\end{array}$ & $\begin{array}{c}\text { Fsu12 } \\
\text { (ksi) }\end{array}$ \\
\hline $\mathbf{1 0 , 7 5 , 1 5}$ & 98.5 & 16.8 & 5.02 & 0.194 & 16.7 & 5.02 & 0.194 & 1.16 & 101 & 31.8 & 82.4 & 24.7 & 8.50 \\
\hline
\end{tabular}

Et1 $=0^{\circ}$ tensile Young's modulus; Et2 $=90^{\circ}$ tensile Young's modulus; vt12 $=$ in-plane tensile Poisson ratio; Ec1 $=0^{\circ}$ compressive Young's modulus; Ec2 $=90^{\circ}$ compressive Young's modulus; vc12 = in-plane compressive Poisson ratio; G12 = inplane shear modulus; Ftu $1=0^{\circ}$ ultimate tensile stress allowable; Ftu2 $=90^{\circ}$ ultimate tensile stress allowable; Fcu1 $=0^{\circ}$ ultimate compressive stress allowable; Fcu2 $=90^{\circ}$ ultimate compressive stress allowable; Fsu12 $=$ ultimate in-plane shear stress allowable.

TABLE 5.-ARES V FRF INTERSTAGE WEB EFFECTIVE IM7/8552 OPEN HOLE COMPRESSION LAMINATE PROPERTIES AT $120^{\circ} \mathrm{F}$

\begin{tabular}{|c|c|c|c|c|c|c|c|c|c|c|c|c|c|}
\hline $\begin{array}{c}\text { Ply \% } \\
\mathbf{4 5} \mathbf{0}, \mathbf{9 0}\end{array}$ & $\begin{array}{c}\text { Density } \\
\text { (pcf) }\end{array}$ & $\begin{array}{c}\text { Et1 } \\
\text { (Msi) }\end{array}$ & $\begin{array}{c}\text { Et22 } \\
\text { (Msi) }\end{array}$ & $\mathbf{v t 1 2}$ & $\begin{array}{c}\text { Ec1 } \\
\text { (Msi) }\end{array}$ & $\begin{array}{c}\text { Ec2 } \\
\text { (Msi) }\end{array}$ & vc12 & $\begin{array}{c}\text { G12 } \\
\text { (Msi) }\end{array}$ & $\begin{array}{c}\text { Ftu1 } \\
\text { (ksi) }\end{array}$ & $\begin{array}{c}\text { Ftu2 } \\
\text { (ksi) }\end{array}$ & $\begin{array}{c}\text { Fcu1 } \\
\text { (ksi) }\end{array}$ & $\begin{array}{c}\text { Fcu2 } \\
\text { (ksi) }\end{array}$ & $\begin{array}{c}\text { Fsu12 } \\
\text { (ksi) }\end{array}$ \\
\hline $\mathbf{4 0 , 4 5 , 1 5}$ & 98.5 & 11.6 & 6.13 & 0.368 & 11.6 & 6.12 & 0.368 & 2.60 & 63.0 & 37.0 & 56.1 & 30.2 & 19.1 \\
\hline $\mathbf{5 0 , 3 5 , 1 5}$ & 98.5 & 9.86 & 6.34 & 0.410 & 9.86 & 6.34 & 0.410 & 3.08 & 52.0 & 36.7 & 46.8 & 31.3 & 22.6 \\
\hline $\mathbf{5 0 , 2 5 , 2 5}$ & 98.5 & 8.15 & 8.15 & 0.321 & 8.15 & 8.15 & 0.321 & 3.08 & 45.5 & 45.5 & 40.1 & 40.1 & 22.3 \\
\hline
\end{tabular}

Et1 $=0^{\circ}$ tensile Young's modulus; Et2 $=90^{\circ}$ tensile Young's modulus; vt12 $=$ in-plane tensile Poisson ratio; Ec1 $=0^{\circ}$ compressive Young's modulus; Ec2 $=90^{\circ}$ compressive Young's modulus; vc12 = in-plane compressive Poisson ratio; G12 = inplane shear modulus; Ftu $1=0^{\circ}$ ultimate tensile stress allowable; Ftu2 $=90^{\circ}$ ultimate tensile stress allowable; Fcu $1=0^{\circ}$ ultimate compressive stress allowable; Fcu2 $=90^{\circ}$ ultimate compressive stress allowable; Fsu12 = ultimate in-plane shear stress allowable.

Although, as mentioned above, the FEM contains no ring frames, the effect of ring frame spacing on the FRF panel weights for the interstage were investigated by varying the panel axial buckling length within HyperSizer. This panel buckling length is used in the panel buckling analysis within HyperSizer to determine the allowable buckling load. It is typically taken as the distance between ring frames, which assumes that the ring frames provide sufficient constraint such that the panel buckling modes are restricted to within the bays. The axial buckling length was varied between 15 and 90 in., while, in the circumferential direction, full cylinder buckling was assumed.

Figure 11 shows a plot of the sized interstage panel areal weight versus ring frame spacing for the two employed sizing approaches. Details of the designs for 30, 60, and 90 in. ring frame spacings are given in Table 6. As expected, for both sizing approaches, as the ring frame spacing (and thus buckling length) increases, the panel height becomes greater to prevent panel buckling, and the panel areal weight increases. For the lower ring frame spacings, the weights of the FRF panels sized with the effective core property approach and the blade stiffened sandwich panel approach are reasonably close. However, as the ring frame spacing increases, the weight associated with the effective core property approach becomes significantly lower than that associated with the blade stiffened sandwich approach. This higher weight of the blade stiffened sandwich design is due to the higher web weight caused by the taller and thicker webs. The thicker webs are required to prevent local buckling of the webs as they become taller in concert with the panel height. In the effective core property sizing approach, since the webs are not explicitly modeled, and thus local buckling of the webs is not explicitly considered, this effect is not considered in the sizing. This demonstrates the need for a true HyperSizer capability for FRF panels, that considers the local buckling of the webs and facesheet with the added support of the foam. 


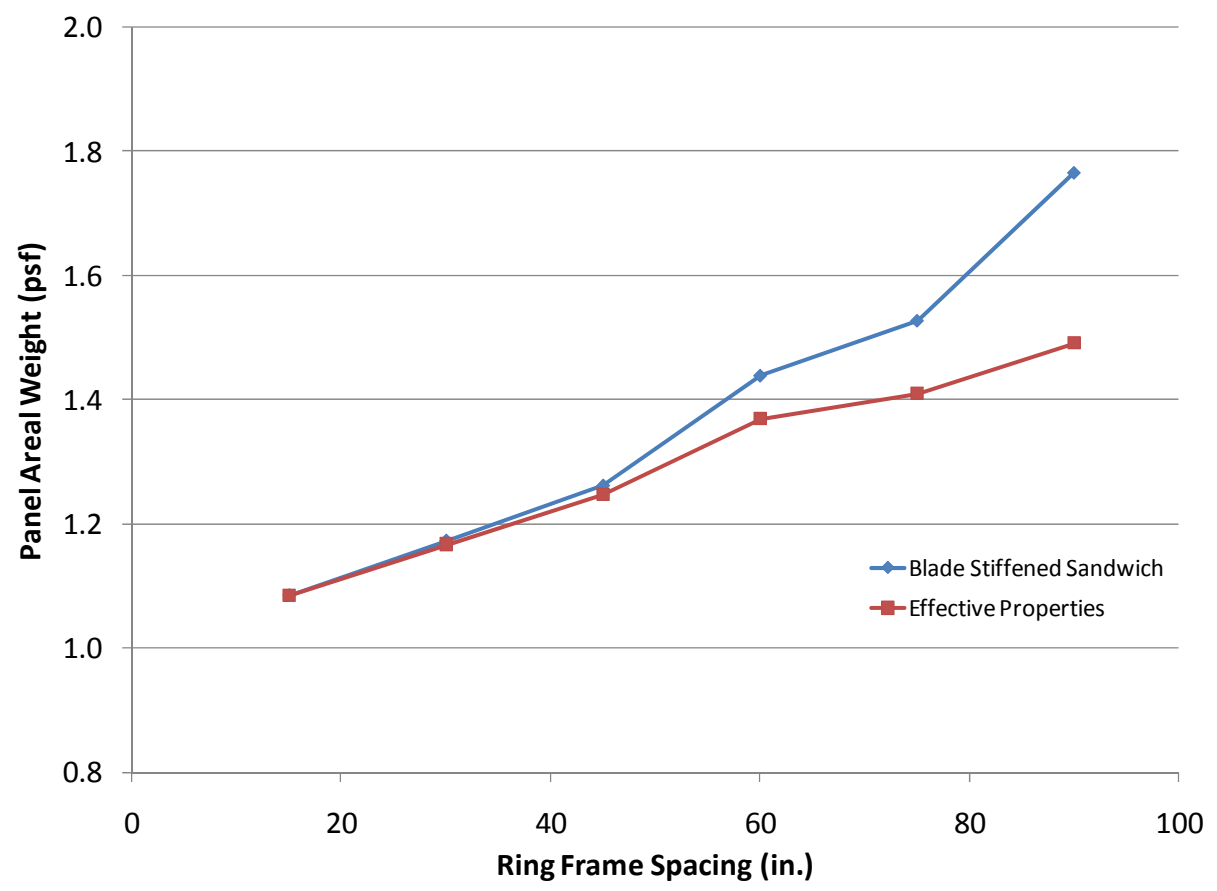

Figure 11.-Ares $\mathrm{V}$ sized interstage panel areal weight versus ring frame spacing for the effective core property and blade stiffened sandwich sizing approaches.

TABLE 6.-DESIGN DETAILS OF THE FRF INTERSTAGE PANELS AS A FUNCTION OF RING FRAME SPACING

\begin{tabular}{|l|c|c|c|c|c|c|}
\hline \multicolumn{1}{|c|}{ Ring Spacing } & \multicolumn{2}{|c|}{30 ” } & \multicolumn{2}{c|}{60 ” } & \multicolumn{2}{c|}{90 " } \\
\hline & $\begin{array}{c}\text { Effective } \\
\text { Props }\end{array}$ & $\begin{array}{c}\text { Blade } \\
\text { Sandwich }\end{array}$ & $\begin{array}{c}\text { Effective } \\
\text { Props }\end{array}$ & $\begin{array}{c}\text { Blade } \\
\text { Sandwich }\end{array}$ & $\begin{array}{c}\text { Effective } \\
\text { Props }\end{array}$ & $\begin{array}{c}\text { Blade } \\
\text { Sandwich }\end{array}$ \\
\hline Areal Weight (Ib/ft') & 1.17 & 1.17 & 1.37 & 1.44 & 1.49 & 1.77 \\
\hline $\begin{array}{l}\text { Equivalent Facesheet } \\
\text { Thickness (plies) }\end{array}$ & 9 & 8 & 9 & 8 & 9 & 8 \\
\hline Panel Height (in) & 1 & 1.25 & 1.625 & 2 & 2 & 2.5 \\
\hline $\begin{array}{l}\text { Equivalent Web } \\
\text { Thickness (plies) }\end{array}$ & - & 4 & - & 6 & - & 8 \\
\hline Web Spacing (in) & - & 1 & - & 1.5 & - & 1.5 \\
\hline
\end{tabular}

\section{Core Intertank}

As shown in Figure 2, the core intertank is located aft of the interstage, and is consequently more highly loaded for this reason alone. In addition, the two SRBs are attached to the core intertank, which introduce a great deal of additional load, and the current design includes a thrust beam spanning the intertank barrel. The Ares V core intertank FEM is shown in Figure 12. As shown, there are a number of panel components, and build-up regions that have been included around the cutouts. The structural concepts considered in the sizing are shown in Figure 13. The SRBs and cut-out panels were not sized. The large thrust beam (which is actually composed of shell elements in the FEM) was sized as solid IM7/8552 (with open-hole compression allowables), while the beam components were sized as IM7/8552 C beams. The core intertank barrel was sized as FRF core sandwich panels, using only the effective core property approach. The effective core properties given in Table 1 were employed for the core, while a number of effective laminates, whose properties are given in Table 7, were considered for the facesheets (as well as the beam solid laminates). Note that a uniaxial laminate was considered as a candidate material in this case. As in the interstage sizing, the thicknesses of the two panel facesheets were required to be the same, and the effective laminate properties were determined within HyperSizer using classical lamination theory. 


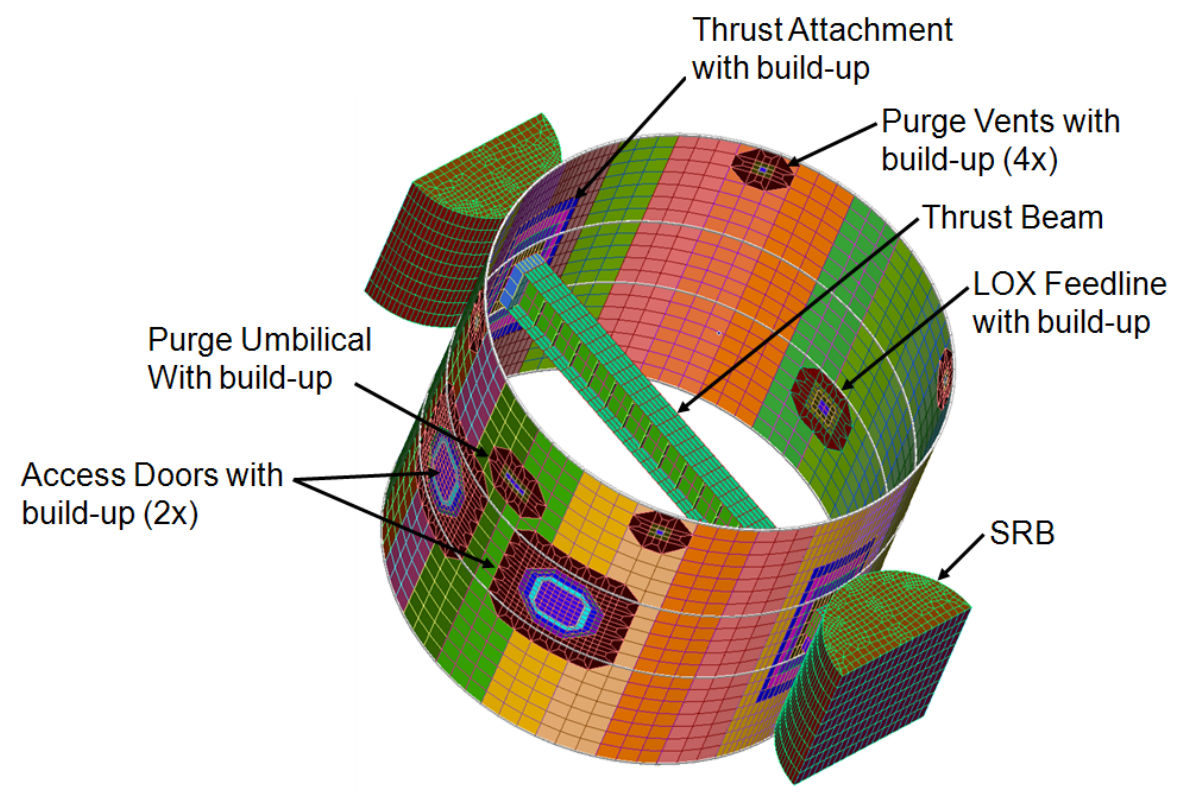

Figure 12.-Ares $\mathrm{V}$ core intertank FEM.

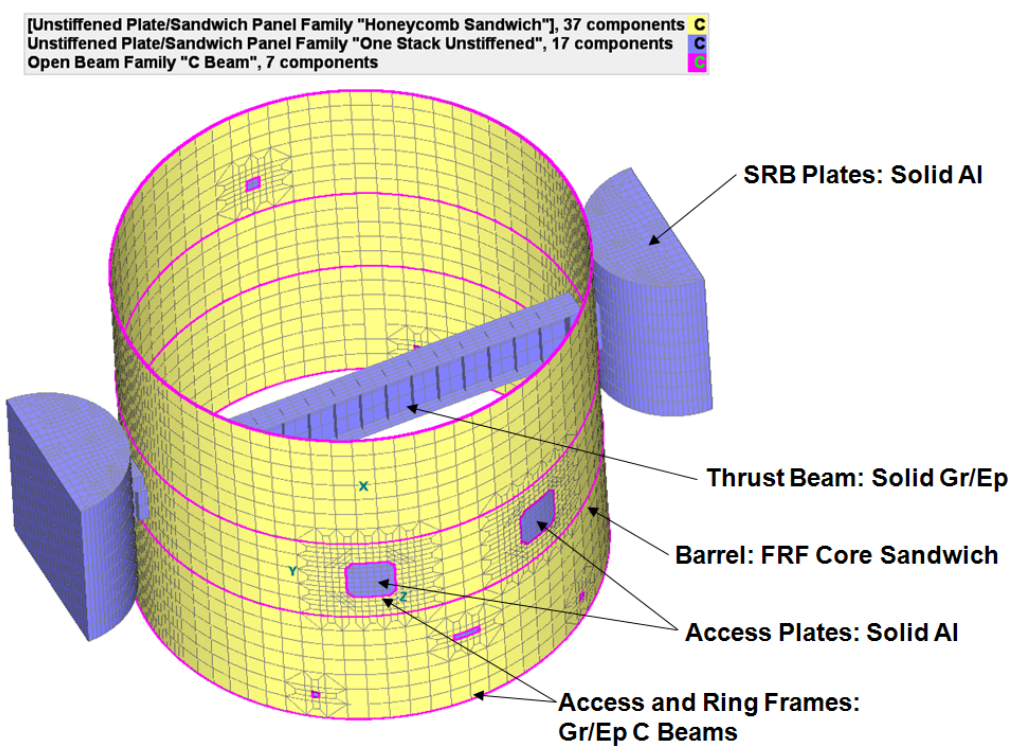

Figure 13.-Ares $\mathrm{V}$ core intertank structural concepts.

TABLE 7.-ARES V FRF CORE INTERTANK FACESHEET EFFECTIVE IM7/8552 OPEN HOLE COMPRESSION LAMINATE PROPERTIES AT $70^{\circ} \mathrm{F}$

\begin{tabular}{|c|c|c|c|c|c|c|c|c|c|c|c|c|c|}
\hline $\begin{array}{c}\text { Ply \% } \\
\mathbf{4 5 ,} \mathbf{0}, \mathbf{9 0}\end{array}$ & $\begin{array}{c}\text { Density } \\
\text { (pcf) }\end{array}$ & $\begin{array}{c}\text { Et1 } \\
\text { (Msi) }\end{array}$ & $\begin{array}{c}\text { Et2 } \\
\text { (Msi) }\end{array}$ & vt12 & $\begin{array}{c}\text { Ec1 } \\
\text { (Msi) }\end{array}$ & $\begin{array}{c}\text { Ec2 } \\
\text { (Msi) }\end{array}$ & vc12 & $\begin{array}{c}\text { G12 } \\
\text { (Msi) }\end{array}$ & $\begin{array}{c}\text { Ftu1 } \\
\text { (ksi) }\end{array}$ & $\begin{array}{c}\text { Ftu2 } \\
\text { (ksi) }\end{array}$ & $\begin{array}{c}\text { Fcu1 } \\
\text { (ksi) }\end{array}$ & $\begin{array}{c}\text { Fcu2 } \\
\text { (ksi) }\end{array}$ & $\begin{array}{c}\text { Fsu12 } \\
\text { (ksi) }\end{array}$ \\
\hline $\mathbf{0 , 1 0 0 , 0}$ & 98.5 & 21.2 & 1.82 & 0.311 & 21.2 & 1.82 & 0.310 & 0.73 & 138 & 11.8 & 103 & 17.1 & 7.1 \\
\hline $\mathbf{2 0}, \mathbf{7 0}, \mathbf{1 0}$ & 98.5 & 16.0 & 4.64 & 0.319 & 16.0 & 4.64 & 0.319 & 1.69 & 80.3 & 28.0 & 67.3 & 21.7 & 10.5 \\
\hline $\mathbf{5 0 , 2 5 , \mathbf { 2 5 }}$ & 98.5 & 8.26 & 8.26 & 0.321 & 8.26 & 8.26 & 0.321 & 3.12 & 41.3 & 41.3 & 34.7 & 34.7 & 19.5 \\
\hline $\mathbf{8 0 , 1 0 , 1 0}$ & 98.5 & 5.29 & 5.29 & 0.566 & 5.29 & 5.29 & 0.566 & 4.56 & 21.9 & 21.9 & 19.6 & 19.6 & 28.4 \\
\hline
\end{tabular}

Et1 $=0^{\circ}$ tensile Young's modulus; Et2 $=90^{\circ}$ tensile Young's modulus; vt12 $=$ in-plane tensile Poisson ratio; Ec1 $=0^{\circ}$ compressive Young's modulus; Ec2 $=90^{\circ}$ compressive Young's modulus; $v$ c12 = in-plane compressive Poisson ratio; G12 = inplane shear modulus; Ftu $1=0^{\circ}$ ultimate tensile stress allowable; Ftu2 $=90^{\circ}$ ultimate tensile stress allowable; Fcu1 $=0^{\circ}$ ultimate compressive stress allowable; Fcu $2=90^{\circ}$ ultimate compressive stress allowable; Fsu12 $=$ ultimate in-plane shear stress allowable. 
Four load cases were developed based on the current Ares V project maximum launch loads at the stations of the stack representing the top and bottom of the intertank barrel, combined with the SRB loads. In all four load cases, the SRB loads are applied to the center surface of the SRB as modeled in the FEM (see Fig. 12). For loading applied to the top of the core intertank, the bottom of the core intertank was fixed. Maximum and minimum axial compressive loads were applied to the top edge of the barrel, with linear variation between these limits around the perimeter of the edge. Two load cases resulted from these top-edge loads by applying the maximum compressive load above the purge umbilical cut-out and the minimum compressive load at $180^{\circ}$ from this location, and then interchanging these locations for the second load case. Similarly, for loading at the bottom of the core intertank, the top-edge of the barrel is held fixed. A maximum compressive axial load and a minimum axial compressive load were applied to the bottom of the barrel, with a $180^{\circ}$ rotation resulting in the two additional load cases. As in the case of the shroud and interstage, the magnitudes of the intertank loads are not currently releasable. Load factors of 1.4 and 1.0 were employed for ultimate and limit, respectively, and a panel buckling knockdown factor of 0.65 was used.

HyperFEA was used to iterate between the HyperSizer sizing and the NASTRAN loads FEM. A converged, closed design was achieved after approximately 45 iterations, wherein a multitude of changes in the sizing parameters were made between iterations. The result, as shown in Figure 14, yielded all positive margins, aside from the cut-out panels, which, as in the payload shroud design, were purposely assigned a fixed weak design such that they do not carry significant load. The controlling load case for the barrel panel components is shown in Figure 15. As expected, the load cases labeled " $+Z$ ", wherein the maximum compressive loads are applied above or below the umbilical purge cut-out, are controlling on the side of the barrel that contains the umbilical purge cut-out. Likewise, the opposite side is controlled by the load cases labeled " $-Z$ ". The unit weights of the panels composing the core intertank barrel are shown in Figure 16. Clearly, the build-ups around the cut-outs are becoming quite heavy. The reason for this can be seen in Figures 17 and 18, which show the sized core material and panel thickness. In the build-up regions around the cut-outs and near the thrust beam, a heavy core material was required, as was a panel thickness of up to $0.1524 \mathrm{~m}$ (6 in.).

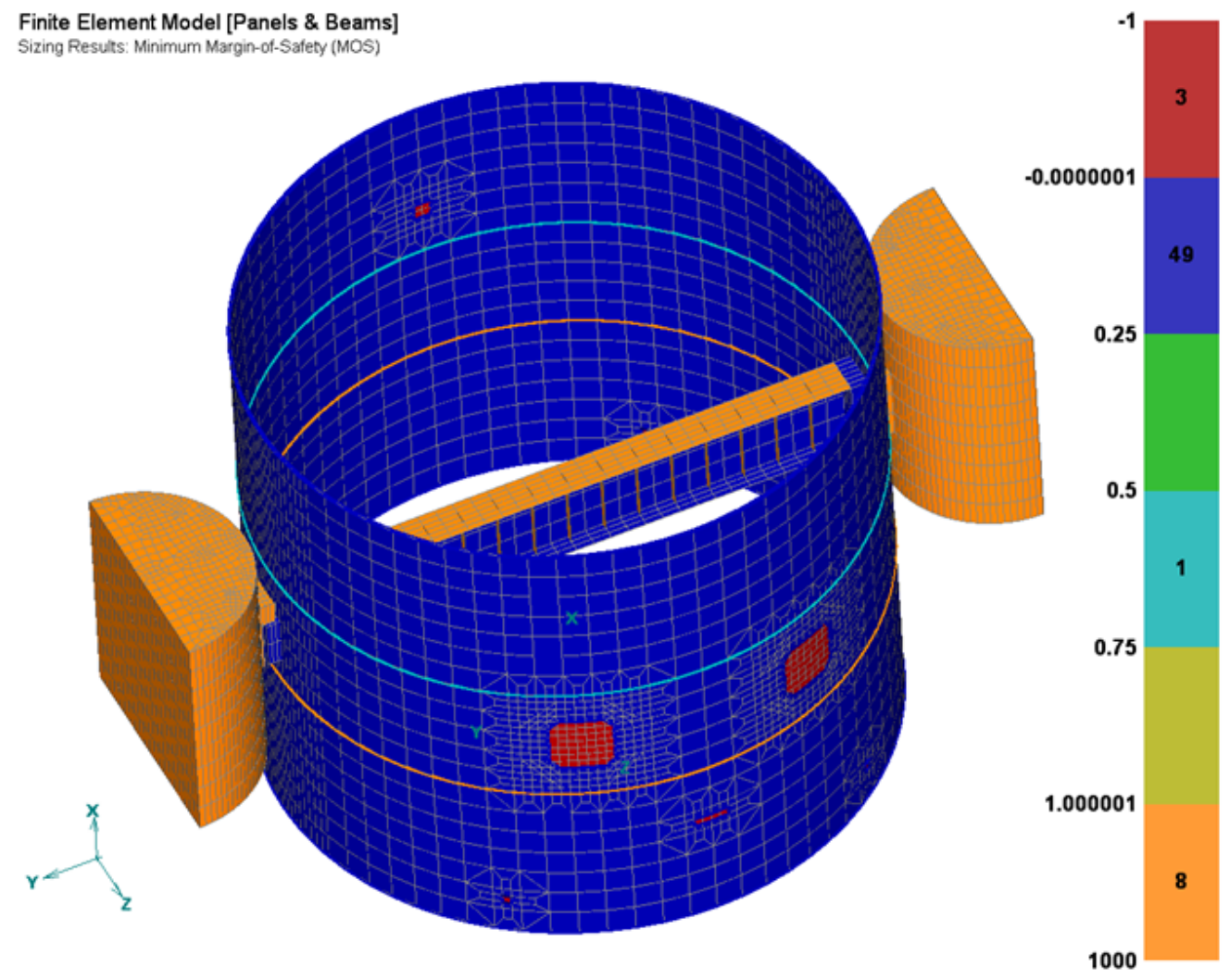

Figure 14.-Ares $V$ core intertank FRF design margins of safety. 


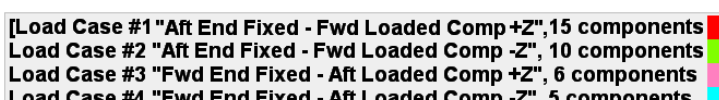

Load Case \#3 "Fwd End Fixed - Aft Loaded Comp +Z", 6 components

Load Case \#4 "Fwd End Fixed - Aft Loaded Comp -Z", 5 components

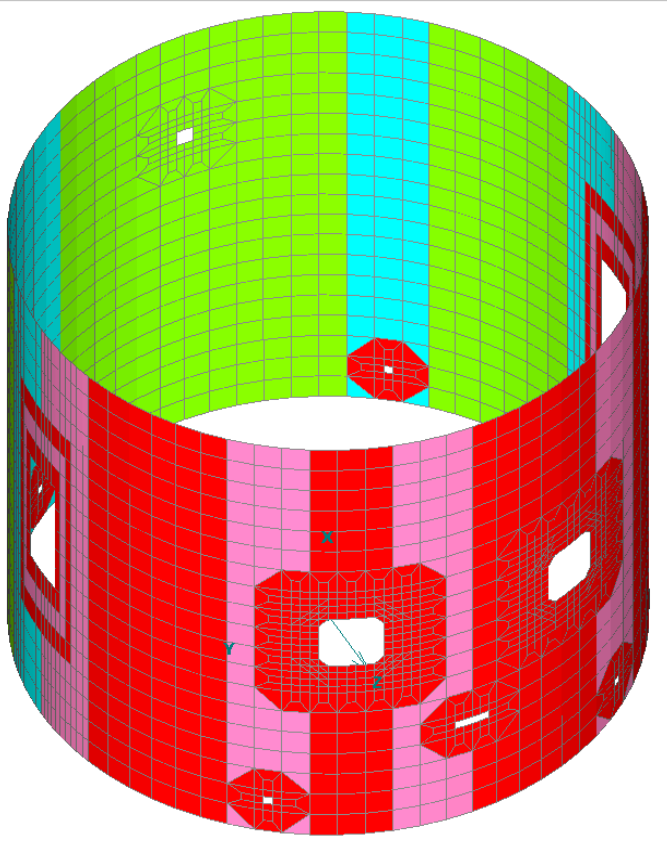

Figure 15.-Ares $V$ core intertank FRF barrel design panel controlling load case.

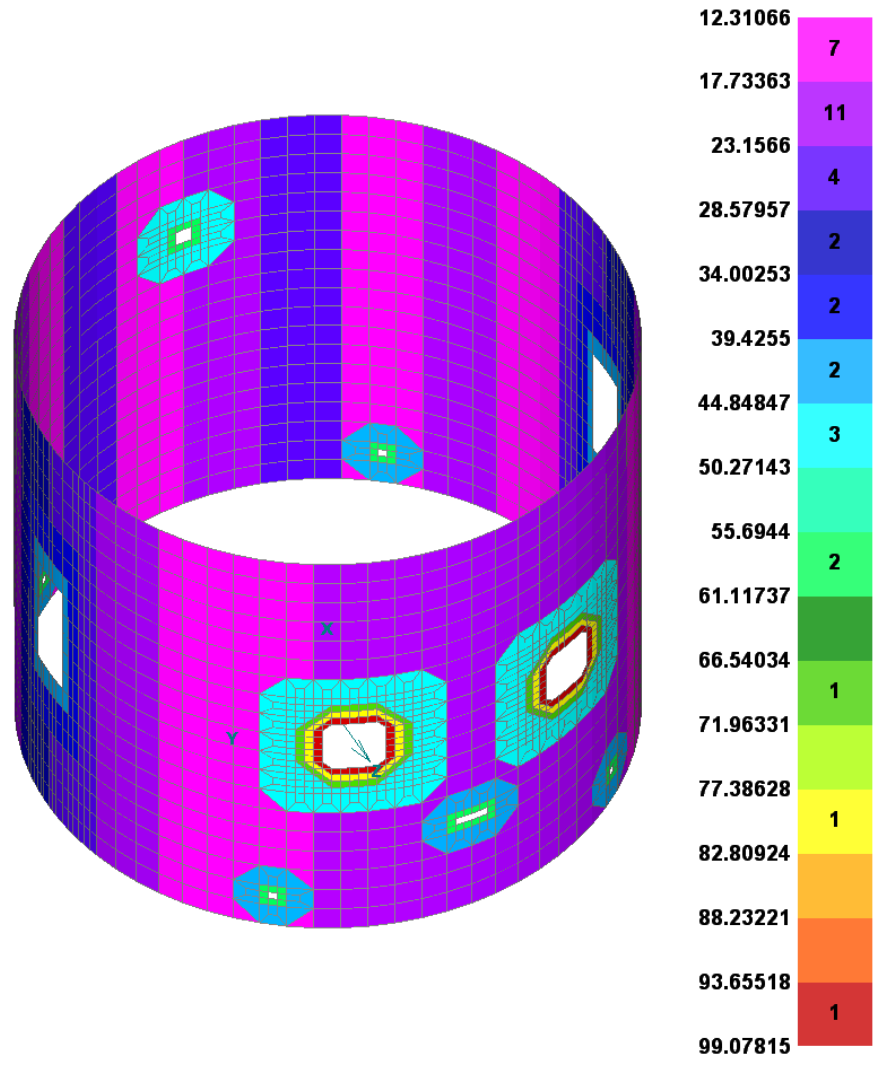

Figure 16. -Ares $V$ core intertank FRF barrel design panel unit weights $\left(\mathrm{kg} / \mathrm{m}^{2}\right)$. 


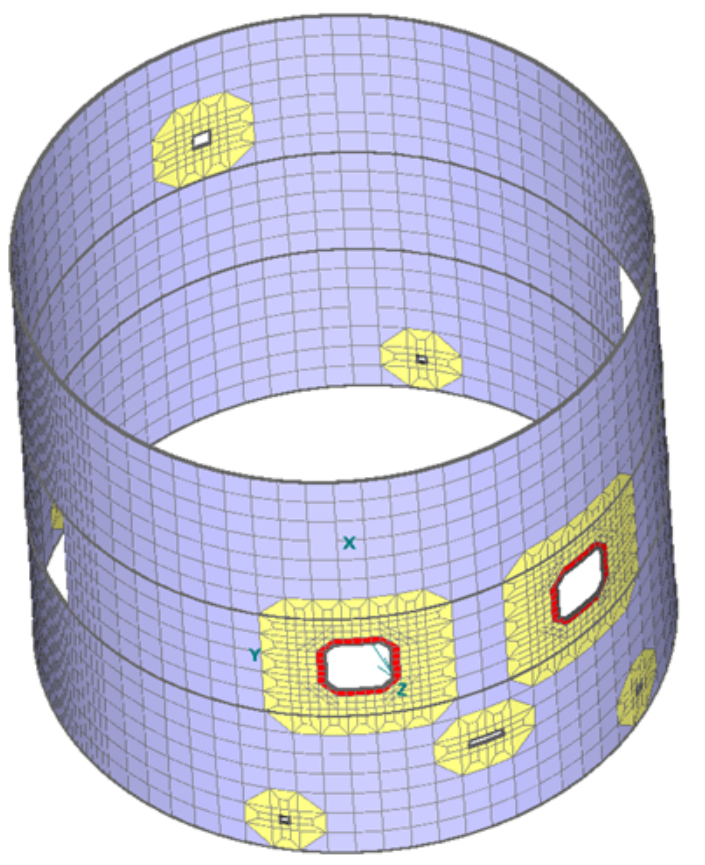

Figure 17.-Ares $V$ core intertank FRF barrel design core material.
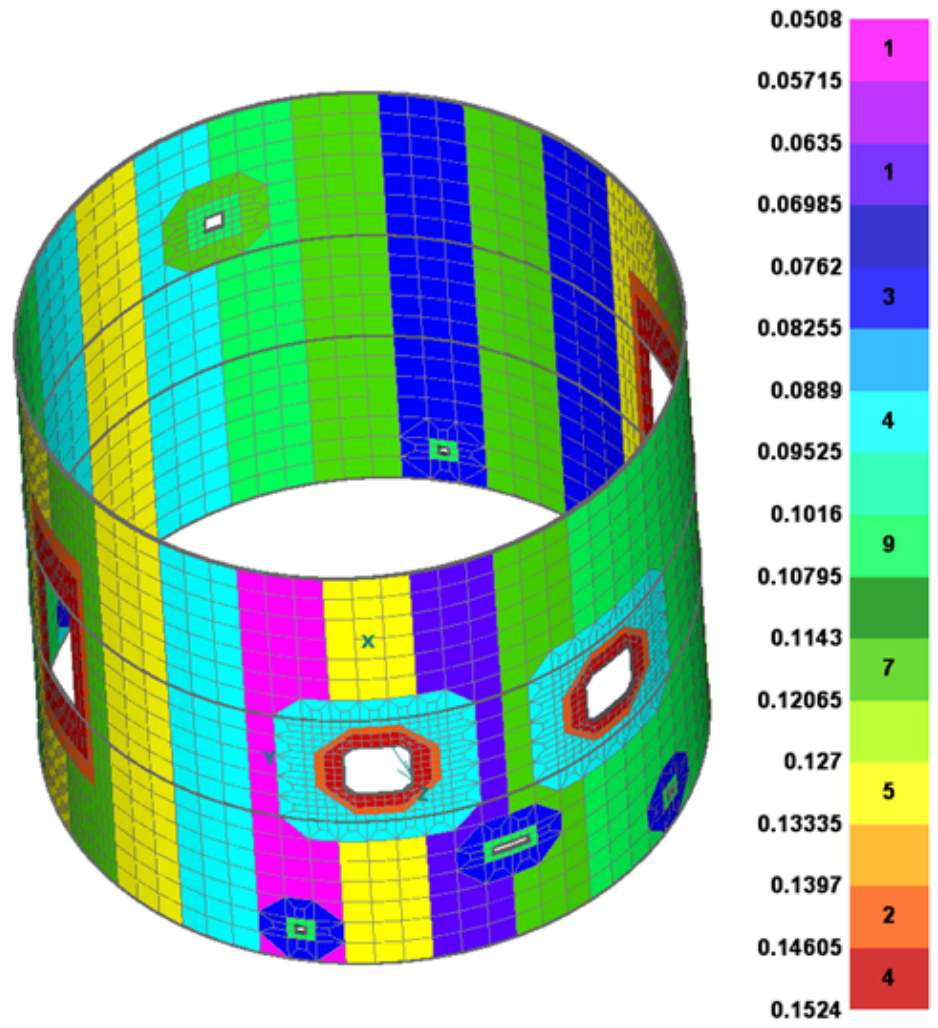

Figure 18.-Ares $V$ core intertank FRF barrel design panel thickness $(m)$. 
Figure 19 shows the facesheet materials selected for the core intertank barrel. Due to the high axial compressive loads, the barrel has been mainly sized with the unidirectional effective laminate facesheets. Likewise, the thrust beam is sized completely with the unidirectional effective laminate material (not shown). The thrust beam laminate thicknesses are shown in Figure 20. The thicknesses of the thrust beam components (which are shell elements) range from 0.1 to 0.8 in.

Figure 21 shows an additional structural component of the core intertank that appears to be problematic. This is one of the thrust adapters that connects the thrust beam and SRBs to the barrel. The portion of the thrust adapter shown in red required $0.141 \mathrm{~m}$ (5.6 in.) solid laminate due to the high loads experienced by this panel. Table 8 provides a mass summary of the core intertank FRF design. The structure depicted in Figure 21 consists of the thrust adapter and thrust adapter - on barrel, each of which have a mass greater than that of the entire thrust beam. Clearly, this region of the structure is a strong candidate for significant redesign.

[[EL*] Effective Laminates "IM7/8552 OHC - Mil-HNBK-17", Form: Tape, Dry], 23 components [EL*] Effective Laminates "NASA ACT Interstage_Gr/Ep: IM7/8552 OHC (20\% 45), (70\% 0), (10\% 90)", Dry, 4 components [EL*] Effective Laminates "NASA_ACT_Interstage_Gr/Ep: IM7/8552 OHC (50\% 45), (25\% 0), (25\% 90)", Dry, 9 components

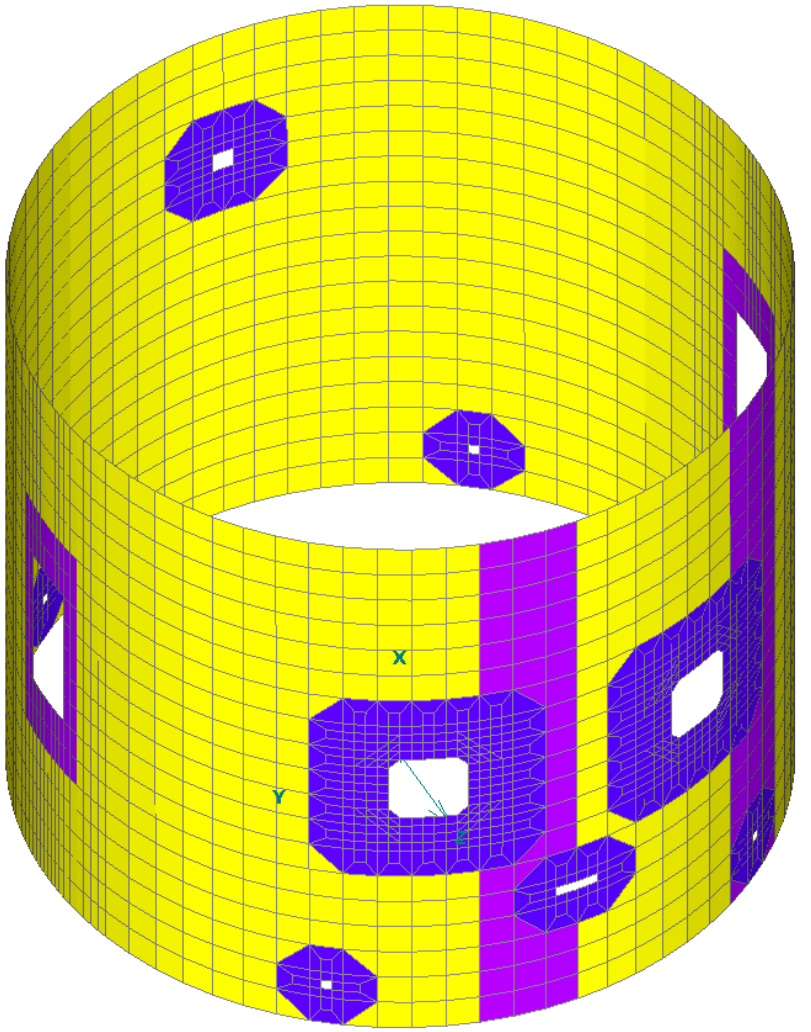

Figure 19.-Ares $V$ core intertank FRF barrel design facesheet materials. 


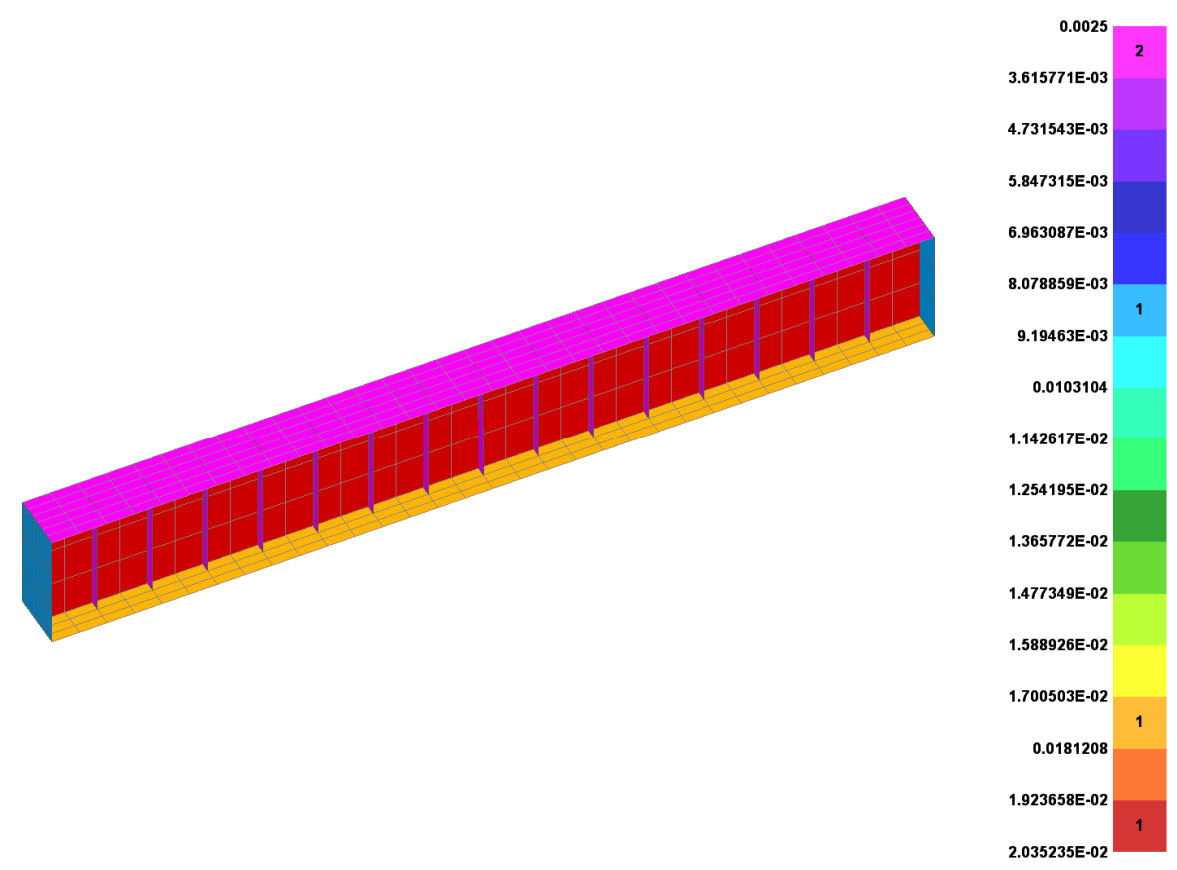

Figure 20.—Ares V FRF core intertank design thrust beam laminate thicknesses $(\mathrm{m})$.
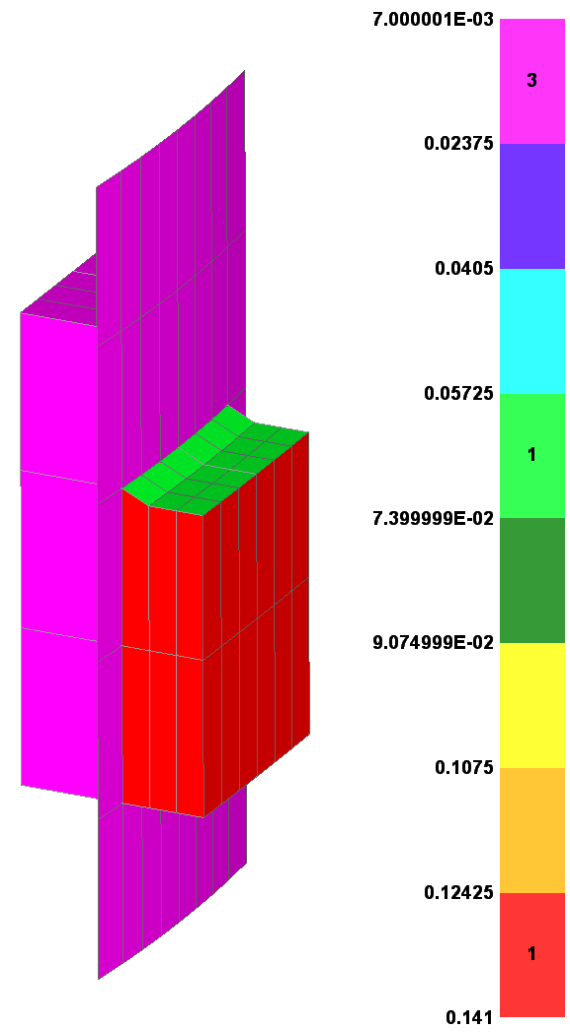

Figure 21.-Ares V FRF core intertank design thrust adapter laminate thicknesses ( $m$ ). 


\begin{tabular}{|c|c|c|}
\hline Group / Component & $\begin{array}{l}\text { Unit Weight } \\
\left(\mathrm{kg} / \mathrm{m}^{\wedge} 2\right)\end{array}$ & $\begin{array}{c}\text { Lowest } \\
\text { MS }\end{array}$ \\
\hline 1 "Thrust Beam" & 20.7 & 0.02894 \\
\hline 2 "Thrust Adapter" & 104.7 & 0.007755 \\
\hline 3 "Thrust Adapter - on Barrel" & 43.9 & 0.0046 \\
\hline 10 "Barrel" & 19.8 & 0.0009455 \\
\hline 11 "Access Doors" & 57.33 & 0.00559 \\
\hline 12 "Purge Penetrations" & 45.03 & 0.004834 \\
\hline 13 "LOX Feed Line" & 46.49 & 0.005318 \\
\hline 14 "Penetration Plates" & 1.578 & -0.992 \\
\hline 101 "SRB Plates" & 285.1 & 1.457 \\
\hline Group / Component & $\begin{array}{l}\text { Unit Weight } \\
\qquad(\mathrm{kg} / \mathrm{m})\end{array}$ & $\begin{array}{c}\text { Lowest } \\
\text { MS }\end{array}$ \\
\hline 20 "Ring Frames" & 1.66 & 0.04497 \\
\hline 21 "Penetration Frames" & 0.7622 & 0.0191 \\
\hline
\end{tabular}

\section{Conclusion}

A preliminary design study for the Ares $\mathrm{V}$ payload shroud, interstage, and core intertank has been presented, where a novel fiber reinforced foam (FRF) sandwich panel concept has been employed. This lightweight panel concept is essentially a hybrid between a foam sandwich panel and a blade stiffened sandwich panel, where integral webs are present within the panel core, separated by foam. Two approaches for sizing the FRF panels, using vendorsupplied effective core properties and treating the panel as a blade stiffened sandwich panel, were used for the shroud and the interstage. The design of the more complex core intertank was performed using only the effective core property approach. It was found that both approaches are capable of achieving closed preliminary designs, and for lower panel heights $(<\sim 1.5 \mathrm{in}$.) the approaches produce design masses that are in reasonable agreement. Under sufficient load, as the panels become thicker, as they will when compressive loads or the panel buckling length increase, local buckling of the webs becomes a more critical failure mode. This increases the mass of the FRF panel when using the blade stiffened sandwich design approach, but does not affect the design in the case of the effective core property approach as local buckling of the webs is not explicitly considered. As such, the blade stiffened panel approach tends to yield heavier panel designs as the panel thickness increases. Conversely, in the case of the shroud design, which is lightly loaded compared to the interstage, local web buckling does not become an issue, and the blade stiffened panel approach resulted in a lower mass design. This illustrates that using effective properties under conditions that deviate significantly from the conditions under which the effective properties were determined has the potential to yield nonconservative designs.

\section{References}

1. Stoll, F., Day, S., Campbell, S., Banerjee, R., Sheppard, M., and Lang, E., "Advancements in Engineered Composite Sandwich Core Materials," SAMPE 2006, May, Long Beach, CA, 2006.

2. WebCore Technologies, Inc., Miamisburg, OH, http://www.webcoreonline.com/.

3. NEi NASTRAN, Noran Engineering, Inc., Westminster, CA, http://www.nenastran.com/.

4. HyperSizer Structural Sizing Software, Collier Research Corp., Hampton, VA, http://www.hypersizer.com, 2009.

5. HyperFEA, Collier Research Corp., Hampton, VA, http://www.hypersizer.com/pdf/brochure_HyperFEA.pdf, 2009.

6. Bednarcyk, B.A., Arnold, S.M., Collier, C.S., and Yarrington, P.W. "Preliminary Structural Sizing and Alternative Material Trade Study for CEV Crew Module," 48th AIAA/ASME/ASCE/AHS/ASC Structures, Structural Dynamics, and Materials Conference, Honolulu, HI, April, 2007.

7. Sheppard, M., WebCore Technologies, Inc., Personal Communication, February, 2009.

8. Evonic Industries, Rohacell IG/IG-F Datasheet, http://www.rohacell.com/en/performanceplastics8344.html, Aug., 2009.

9. Knight, N.F., "Nonlinear Shell Analyses of the SRB/ETA Ring Interface," NASA TM 89164, July, 1987. 


\begin{tabular}{|c|c|c|}
\hline \multicolumn{2}{|c|}{ REPORT DOCUMENTATION PAGE } & $\begin{array}{l}\text { Form Approved } \\
\text { OMB No. 0704-0188 }\end{array}$ \\
\hline \multicolumn{3}{|c|}{ 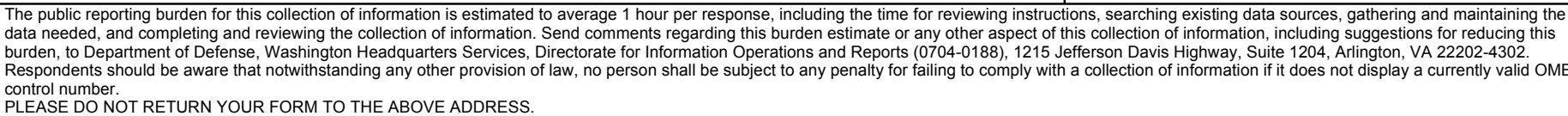 } \\
\hline $\begin{array}{l}\text { 1. REPORT DATE (DD-MM-YYYY) } \\
01-10-2010\end{array}$ & $\begin{array}{l}\text { 2. REPORT TYPE } \\
\text { Technical Memorandum }\end{array}$ & 3. DATES COVERED (From - To) \\
\hline \multirow{3}{*}{\multicolumn{2}{|c|}{$\begin{array}{l}\text { 4. TITLE AND SUBTITLE } \\
\text { Design of Fiber Reinforced Foam Sandwich Panels for Large Ares }\end{array}$}} & 5a. CONTRACT NUMBER \\
\hline & & 5b. GRANT NUMBER \\
\hline & & 5c. PROGRAM ELEMENT NUMBER \\
\hline \multirow{3}{*}{\multicolumn{2}{|c|}{$\begin{array}{l}\text { 6. AUTHOR(S) } \\
\text { Bednarcyk, Brett, A.; Arnold, Steven, M.; Hopkins, Dale, A. }\end{array}$}} & 5d. PROJECT NUMBER \\
\hline & & 5e. TASK NUMBER \\
\hline & & $\begin{array}{l}\text { 5f. WORK UNIT NUMBER } \\
\text { WBS } 727950.04 .03 .22\end{array}$ \\
\hline \multicolumn{2}{|c|}{$\begin{array}{l}\text { 7. PERFORMING ORGANIZATION NAME(S) AND ADDRESS(ES) } \\
\text { National Aeronautics and Space Administration } \\
\text { John H. Glenn Research Center at Lewis Field } \\
\text { Cleveland, Ohio 44135-3191 }\end{array}$} & $\begin{array}{l}\text { 8. PERFORMING ORGANIZATION } \\
\text { REPORT NUMBER } \\
\text { E-17452 }\end{array}$ \\
\hline \multirow{2}{*}{\multicolumn{2}{|c|}{$\begin{array}{l}\text { 9. SPONSORING/MONITORING AGENCY NAME(S) AND ADDRESS(ES) } \\
\text { National Aeronautics and Space Administration } \\
\text { Washington, DC 20546-0001 }\end{array}$}} & $\begin{array}{l}\text { 10. SPONSORING/MONITOR'S } \\
\text { ACRONYM(S) } \\
\text { NASA }\end{array}$ \\
\hline & & $\begin{array}{l}\text { 11. SPONSORING/MONITORING } \\
\text { REPORT NUMBER } \\
\text { NASA/TM-2010-216823 }\end{array}$ \\
\hline \multicolumn{3}{|c|}{$\begin{array}{l}\text { 12. DISTRIBUTION/AVAILABILITY STATEMENT } \\
\text { Unclassified-Unlimited } \\
\text { Subject Category: } 39 \\
\text { Available electronically at http://gltrs.grc.nasa.gov } \\
\text { This publication is available from the NASA Center for AeroSpace Information, 443-757-5802 }\end{array}$} \\
\hline
\end{tabular}

\section{SUPPLEMENTARY NOTES}

\section{ABSTRACT}

The preliminary design of three major structural components within NASA's Ares V heavy lift vehicle using a novel fiber reinforced foam composite sandwich panel concept is presented. The Ares V payload shroud, interstage, and core intertank are designed for minimum mass using this panel concept, which consists of integral composite webs separated by structural foam between two composite facesheets. The HyperSizer structural sizing software, in conjunction with NASTRAN finite element analyses, is used. However, since HyperSizer does not currently include a panel concept for fiber reinforced foam, the sizing was performed using two separate approaches. In the first, the panel core is treated as an effective (homogenized) material, whose properties are provided by the vendor. In the second approach, the panel is treated as a blade stiffened sandwich panel, with the mass of the foam added after completion of the panel sizing. Details of the sizing for each of the three Ares V components are given, and it is demonstrated that the two panel sizing approaches are in reasonable agreement for thinner panel designs, but as the panel thickness increases, the blade stiffened sandwich panel approach yields heavier panel designs. This is due to the effects of local buckling, which are not considered in the effective core property approach.

\section{SUBJECT TERMS}

Composites; Sandwich panels; Preliminary design; Local buckling; Structural sizing; Laminates

\begin{tabular}{|l|l|l|l|l|l|}
\hline \multicolumn{2}{|l|}{ 16. SECURITY CLASSIFICATION OF: } & $\begin{array}{l}\text { 17. LIMITATION OF } \\
\text { ABSTRACT }\end{array}$ & $\begin{array}{l}\text { 18. NUMBER } \\
\text { OF } \\
\text { PAGES }\end{array}$ & $\begin{array}{l}\text { 19a. NAME OF RESPONSIBLE PERSON } \\
\text { STI Help Desk (email:help@sti.nasa.gov) }\end{array}$ \\
\cline { 1 - 1 } $\begin{array}{l}\text { a. REPORT } \\
\text { U }\end{array}$ & $\begin{array}{l}\text { b. ABSTRACT } \\
\text { S }\end{array}$ & $\begin{array}{l}\text { C. THIS } \\
\text { PAGE } \\
\text { U }\end{array}$ & UU & 24 & $\begin{array}{l}\text { 19b. TELEPHONE NUMBER (include area code) } \\
443-757-5802\end{array}$ \\
\hline
\end{tabular}



